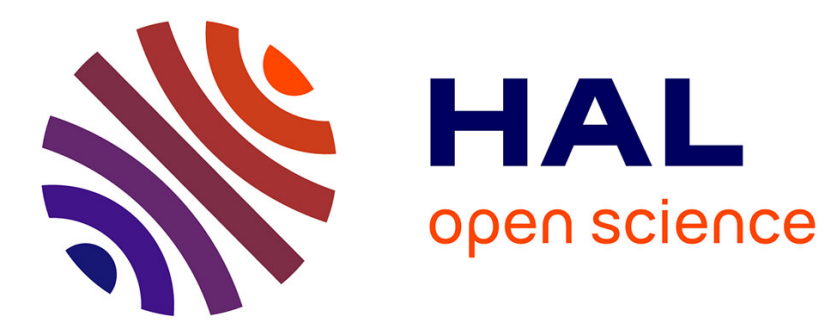

\title{
Intraseasonal to interannual modulation of diurnal precipitation distribution over Eastern Africa.
}

Pierre Camberlin, Wilson Gitau, George N Kiladis, Emily Bosire, Benjamin Pohl

\section{- To cite this version:}

Pierre Camberlin, Wilson Gitau, George N Kiladis, Emily Bosire, Benjamin Pohl. Intraseasonal to interannual modulation of diurnal precipitation distribution over Eastern Africa.. Journal of Geophysical Research: Atmospheres, 2019, 124 (22), pp.11863-11886. 10.1029/2019JD031167 . hal-02430780

\section{HAL Id: hal-02430780 \\ https://hal.science/hal-02430780}

Submitted on 12 Jan 2022

HAL is a multi-disciplinary open access archive for the deposit and dissemination of scientific research documents, whether they are published or not. The documents may come from teaching and research institutions in France or abroad, or from public or private research centers.
L'archive ouverte pluridisciplinaire HAL, est destinée au dépôt et à la diffusion de documents scientifiques de niveau recherche, publiés ou non, émanant des établissements d'enseignement et de recherche français ou étrangers, des laboratoires publics ou privés. 


\section{JGR Atmospheres}

\section{RESEARCH ARTICLE 10.1029/2019JD031167 \\ Intraseasonal to Interannual Modulation of Diurnal Precipitation Distribution Over Eastern Africa}

Key Points:

- Diurnal rainfall distribution over Eastern Africa and the nearby Indian Ocean is modulated at intraseasonal and interannual time scales

- The Madden-Julian Oscillation mainly affects the diurnal cycle amplitude, especially by enhancing or weakening the late afternoon peak

- The Indian Ocean Dipole Mode also mostly affects the amplitude, but notable changes occur in the phase of the rains over some land areas

Supporting Information:

- Supporting Information S1

- Figure S1

Correspondence to:

P. Camberlin,

camber@u-bourgogne.fr

Citation:

Camberlin, P., Gitau, W., Kiladis, G. Bosire, E., \& Pohl, B. (2019). Intraseasonal to interannual modulation of diurnal precipitation distribution over Eastern Africa. Journal of Geophysical Research: Atmospheres, 124, 11,863-11,886. https://doi.org/10.1029/2019JD031167

Received 18 JUN 2019 Accepted 22 SEP 2019

Accepted article online 22 NOV 2019

Published online 24 NOV 2019

(C)2019. American Geophysical Union. All Rights Reserved.

\author{
Pierre Camberlin $^{1}$ iD, Wilson Gitau ${ }^{2}$ iD, George Kiladis ${ }^{3}$, Emily Bosire $^{2}$, and Benjamin Pohl ${ }^{1}$ \\ ${ }^{1}$ Centre de Recherches de Climatologie/Biogéosciences, UMR 6282 CNRS/Université Bourgogne Franche-Comté, Dijon \\ Cedex, France, ${ }^{2}$ Department of Meteorology, University of Nairobi, Nairobi, Kenya, ${ }^{3}$ Physical Sciences Division R/PSD1, \\ Earth System Research Laboratory, NOAA, Boulder, CO, USA
}

\begin{abstract}
The modulation of the rainfall diurnal cycle at intraseasonal and interannual time scales is examined using gridded rainfall data over Eastern Africa and the nearby Indian Ocean for the period 1998-2014. Our focus is on the October-December season which is strongly impacted by both the Madden-Julian Oscillation (MJO) and the Indian Ocean Dipole Mode (IODM). The effect of the MJO, which is not synchronized across the whole region, is mainly through changes in the amplitude of the diurnal cycle, especially an enhancement of the late afternoon peak in active phases of the MJO. The rainfall phase only shows minor variations between the active and quiescent phases of the MJO, except over the drier regions and the Indian Ocean where the overall diurnal rainfall signal is more uneven. The effect of the positive phase of the IODM (warm western Indian Ocean) on Eastern Africa rainfall is found at any time of the day, but the enhancement is more prominent during the wettest part of the day (generally the afternoon). Substantial changes in the diurnal phase of the rains are found in some land areas away from the coast or from mountain ranges, where the dominant afternoon peak during the negative IODM phase is replaced by a nighttime maximum during the positive phase. Cross-sections and a cluster analysis of diurnal rainfall patterns over Kenya and southern Somalia suggest that this feature may be associated with the development of longer-lived rainfall systems propagating inland from the coast during the IODM positive phase.
\end{abstract}

\section{Introduction}

Rainfall variability results from processes occurring on a wide range of time scales. In the tropics, interannual, intraseasonal, and diurnal variations are of large magnitudes. El Niño-Southern Oscillation (ENSO), the dominant interannual mode of climate variability at global scale, has a strong signature not only over the Pacific region but across a large part of the tropics, including much of tropical Africa (e.g., Camberlin et al., 2001; Dai \& Wigley, 2000; Kiladis \& Diaz, 1989; Nicholson \& Kim, 1997; Ogallo, 1988; Ropelewski \& Halpert, 1987). The Madden-Julian Oscillation (MJO), the leading intraseasonal mode of climate variability in the tropics, shows its highest variance in convective activity over the central/eastern Indian Ocean and western Pacific Ocean, but a substantial signal is also found over more remote regions (Donald et al., 2006; Matthews et al., 2004; Seo \& Son, 2012; Zaitchik, 2017; Zhang, 2005). The diurnal rainfall cycle captures relatively little variance of the 3-hourly rainfall time series at global scale (Ruane \& Roads, 2007), but is strong locally over many tropical land regions, especially near coastlines, mountain ranges, and lakes (Meisner \& Arkin, 1987; Yang \& Slingo, 2001; Biasutti et al., 2012; Sakaeda et al., 2017). Although Meehl et al. (2001) provided examples and a conceptual model depicting interactions in the climate system from the synoptic to the interannual time scales, the relationships with the diurnal time scale are still not fully understood.

Most previous studies dedicated to the modulation of the diurnal cycle by large-scale climate signals, either intraseasonal (generally the MJO) or interannual (especially ENSO), focused on the Maritime Continent (MC). A majority of them found variations in the amplitude of the diurnal cycle associated with the MJO (Fujita et al., 2011; Kanamori et al., 2013; Lu et al., 2019; Oh et al., 2012; Rauniyar \& Walsh, 2011), but depending on the land, sea, or coastal location, the amplitude is either weakened, mildly, or strongly enhanced. More conflicting results are found regarding the effect of the MJO on the diurnal phase of the rains. Tian et al. (2006) and Suzuki (2009) did not find changes in the timing of the rains during the day between active and suppressed-convection phases of the MJO, while many others did. For example, Sakaeda et al. (2017) showed that the rainfall peak is delayed by a few hours within MJO enhanced 
convection over the tropical warm pool surrounding the MC. Regarding the MC interannual variability, Rauniyar and Walsh (2013) found that the contrast between ocean regions (generally wetter during La Niña) and some regions of the islands (wetter during El Niño) can be attributed to anomalies in the amplitude and characteristics of the diurnal cycle. The dipolar rainfall pattern found in El Niño years over Java island (wetter mountains and drier plains) was specifically attributed to the diurnal cycle amplitude, as a result of strengthened land-sea and mountain-valley breezes (Qian et al., 2010). Similar spatial heterogeneities were found over Borneo island and associated with the interplay between ENSO, weather types, and the diurnal cycle (Qian et al., 2013). Moron et al. (2015) examined how MC weather types are affected by both the MJO and ENSO. Over the islands, they found that an enhanced diurnal cycle during "quiescent" weather types, which are more frequent during the suppressed phase of the MJO and El Niño events. This explains the higher rainfall unexpectedly found over southern Java, western Sumatra, and western Borneo during these phases, which are otherwise detrimental for rainfall over the region overall.

Away from the MC, few studies are available. Over northern Australia, weather regimes do not alter the diurnal phase but consistently increase (or decrease) rainfall amounts at all times (Moron et al., 2019). Over the tropical Andes of Colombia, Poveda et al. (2005) found a greater amplitude of the diurnal cycle of precipitation in both the local westerly phase of the MJO and La Niña events. The diurnal phase is unaltered. Over India, the diurnal cycle of rainfall is robust with respect to ENSO variations (Sen Roy \& Balling, 2007), but active and break phases of the monsoon induce some regionally dependent amount and distribution (Deshpande \& Goswami, 2014). Over Tahiti island, Hopuare et al. (2019) found that both the midnight and afternoon rainfall maxima increase just prior to the onset of the MJO precipitation maximum, as a result of enhanced sea breezes.

On the whole, these studies suggest that analyzing how the diurnal cycle is affected by intraseasonal or interannual variations helps understand the teleconnection mechanisms which control rainfall. It is also particularly useful to explain why the strength (and sometimes the sign) of the correlations may vary locally within a given region.

Due to its complicated topography and large water bodies, Eastern Africa is a region where diurnal rainfall regimes are particularly diverse. Besides the dominant late-afternoon maximum which is characteristic of many tropical land areas, rainfall may peak from late evening to early morning depending on the regions (Camberlin et al., 2017; Figure 1). Several instances are found of apparent phase propagation, that is, from the coast to the interior or west of major mountain ranges and Great Lakes. These patterns are relatively unchanged between the two rainy seasons of March-May and October-December. Another distinctive feature of Eastern Africa rainfall is its large interannual variability, as a result of a strong coupling with large-scale divergent circulation associated with ENSO and the Indian Ocean Dipole Mode (IODM). In particular, one of the two rainy seasons found over equatorial Eastern Africa, the short rains (October-December), experiences heavy rainfall in years of the positive phase of the IODM, when abnormally warm waters are found in the western Indian Ocean and cold waters in the eastern Indian Ocean (Behera et al., 2005; Black, 2005; Black et al., 2003; Ummenhofer et al., 2009). However, it is still unknown whether Eastern Africa diurnal regimes are modulated by the interannual variations of the large-scale forcing mechanisms such as ENSO and the IODM.

On intraseasonal time scales, it is now recognized that precipitation over equatorial Eastern Africa is significantly influenced by the MJO (Berhane \& Zaitchik, 2014; Hogan et al., 2015; Omeny et al., 2008; Pohl and Camberlin, 2006a \& 2006b; Zaitchik, 2017). Enhanced rainfall over the East African Highlands is found when the oscillation displays enhanced convection over the Indian Ocean. This occurs during phase two of the Real-Time Multivariate MJO (RMM) index defined by Wheeler and Hendon (2004). An MJO signal is also noted in East African coastal rainfall, although the peak is found earlier than inland, during phase 8 while large-scale convection is enhanced along the Atlantic Ocean longitudes. Coastal rainfall is then depressed during phases 2 and 3. The reason for this lag between coastal and inland East Africa is not yet fully understood, although Berhane and Zaitchik (2014) found that MJO convection over the MC in October strengthens the Indian Ocean branch of the Walker circulation, leading to stronger atmospheric subsidence over coastal East Africa as well as a stronger Somali Low-Level Jet, which creates shallow frictionally induced coastal subsidence. Since coastal locations also show a diurnal cycle which is different from much of inland East Africa, with a coastal morning maximum replacing the inland afternoon peak 


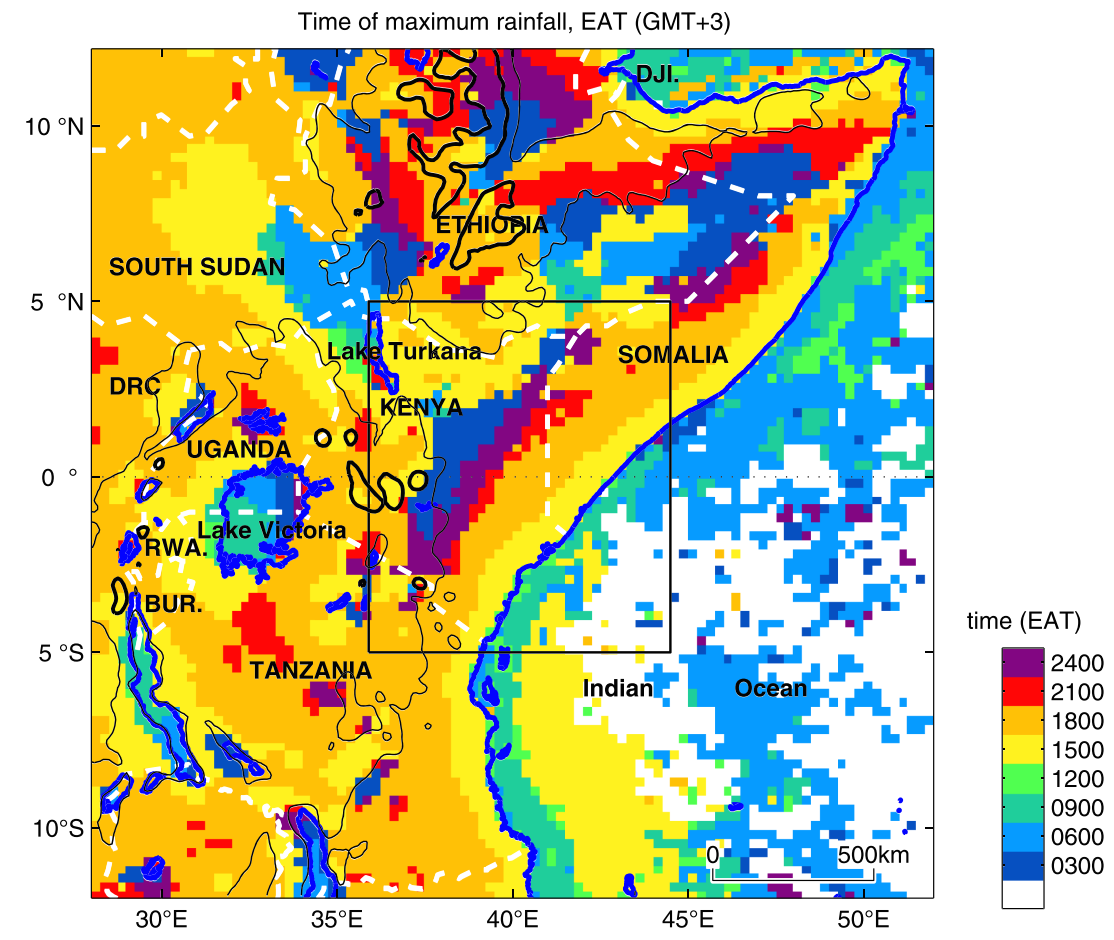

Figure 1. Study area and time of maximum rainfall (EAT $=$ UTC +3$)$, all seasons combined. Black lines: 1,000 $\mathrm{m}$ (thin) and 2,200 $\mathrm{m}$ (thick) elevation contours. White areas: diurnal range between the driest and the wettest 3-hourly periods below $40 \%$ of the rainfall mean. Black box: subregion retained for the cluster analysis in section 5 .

(Camberlin et al., 2017), it is of major interest to find out whether there is a connection between the diurnal regimes and the rainfall response to the MJO over the region.

Studying how the diurnal cycle is modulated at intraseasonal and interannual time scales aims at a better understanding of teleconnection mechanisms over Eastern Africa. As a null hypothesis, we could expect that a given large-scale forcing would simply result in enhanced (or reduced) daytime convection, translated in the diurnal cycle by a larger (smaller) amplitude but unchanged phase of the rains. By contrast, a change in the diurnal phase of the rains (e.g., a delayed diurnal peak, or a completely different diurnal distribution) would suggest that the forcing involves changes in local wind patterns, or in the advection of rain cells. This focus on the diurnal cycle may also help explain possible spatial discrepancies in the strength of the teleconnections, which could result from spatially distinct diurnal cycle patterns. The above literature review of the studies carried out over the MC and other regions highlights the potential utility of considering the interplay between diurnal, intraseasonal, and interannual variations for Eastern Africa. Such scale interactions are addressed through two types of methods. Simple composite analyses are first carried out based on the identification of different phases of the interannual (IODM) and intraseasonal (MJO) forcing patterns. Changes in the mean diurnal rainfall distribution between the different phases are then examined. A second approach is also considered, which first takes into account the fact that mean diurnal cycles may merely reflect statistical patterns, even in terms of diurnal phasing, and are not necessarily adequate to show the actual propagation of the cloud systems during the day. A clustering method is therefore designed to extract the dominant space-time (diurnal) patterns of the rainfall distribution, on a daily basis. The resulting clusters are then projected on intraseasonal and interannual modes of variability. This alternative method was implemented on a subregion, namely, eastern Kenya and southern Somalia, where the mean diurnal rainfall phase shows an apparent shift from early afternoon to nighttime, and which also shows significant relationships with the MJO and Indo-Pacific sea surface temperature anomalies.

\section{Data}

The study is based on 3-hourly rainfall estimates from the TRMM Multi-satellite Precipitation Analysis (TMPA) 3B42 product (Huffman et al., 2007), version 7, at a $0.25^{\circ}$ resolution. TMPA 3B42 incorporates 
microwave and infrared precipitation estimates, calibrated with monthly rain gauge data, and was developed by the Mesoscale Atmospheric Processes Laboratory at NASA Goddard Space Flight Center.

TMPA 3B42 data perform well in reproducing East African rainfall patterns (Cattani et al., 2016). In a previous study, Camberlin et al. (2017) showed that the mean diurnal cycle based on TMPA 3-hourly rainfall estimates compared very favorably to long-term mean hourly rainfall records from independent rain gauge data from Sudan, Ethiopia, Kenya, Somalia, Tanzania, and Uganda. A good agreement with observed diurnal cycles was also found over smaller regions such as the upper Blue Nile and Lake Victoria areas (Haile et al., 2013). Although other studies confirm that at 3-hourly, daily or 10-day time scales TMPA is one of the best rainfall products over the region, some local discrepancies may still be found with rain gauge data over some mountain ranges and rain shadows (Diem et al., 2014; Dinku et al., 2007; Monsieurs et al., 2018). Similarly, over the ocean, no validation of the diurnal cycle can be made against observations. Hence, care has to be taken when examining the results over these areas.

TMPA 3-hourly data from 1998 to 2014 are extracted for the region from $28^{\circ} \mathrm{E}$ to $52^{\circ} \mathrm{E}$ and $12.5^{\circ} \mathrm{S}$ to $12.5^{\circ} \mathrm{N}$. This covers Djibouti, Ethiopia, Somalia, Kenya, Uganda, Rwanda, Burundi, Tanzania, and much of South Sudan (Figure 1). All times are expressed in East African Time (EAT; i.e., GMT+3). In the notations below, 0300 refer to the 3-hr period from 0130 to 0430 EAT, 0600 to the period from 0430 to 0730 , and so on.

Two MJO indices are used. The RMM index defined by Wheeler and Hendon (2004) is a combination of the first two empirical orthogonal functions (EOF) of a principal component analysis applied to unfiltered zonal winds at 850 and $200 \mathrm{hPa}$, and outgoing longwave radiation (OLR) fields after removing the ENSO signal. These two EOF are approximately in quadrature. They together depict the location of the MJO convective clusters within the tropics, conveniently divided into eight phases. For instance, phases 2 and 3 approximately coincide to a maximum of convective activity over the Indian Ocean, phases 4 and 5 over the Maritime Continent, and phases 6 and 7 over western Pacific. The EOF pair also indicates the amplitude of the MJO. Only days with an MJO amplitude greater than 1 are retained in the following composite analyses. New MJO indices have been developed in the recent years, with a varying balance between the convective and dynamical signals associated with the MJO (e.g., Liu et al., 2016; Ventrice et al., 2013)

Hence, we also make use of the OLR-based MJO index (OMI), defined by Kiladis et al. (2014). It is based on convective activity only, and does not take into account atmospheric circulation variables. The use of the OMI has recently been found to be advantageous over other indices in tracking the MJO OLR signal, especially over the Asian monsoon region during northern summer (Wang et al., 2018). Phases equivalent to those of the RMM index can be obtained by combining OMI (PC2), which is analogous to RMM (PC1), and $-1 \mathrm{xOMI}(\mathrm{PC} 1)$ which is analogous to RMM (PC2).

Indian Ocean sea surface temperatures (SSTs), especially the IODM, are the leading driver of interannual variability in equatorial Eastern Africa during the short rains (Behera et al., 2005; Gitau et al., 2015; Hastenrath et al., 1993; Ogallo et al., 1988; Philippon et al., 2002; Ummenhofer et al., 2009). This study uses the Dipole Mode Index (DMI) defined by Saji et al. (1999) and computed as the difference between SST anomalies in the western $\left(50-70^{\circ} \mathrm{E}, 10^{\circ} \mathrm{S}-10^{\circ} \mathrm{N}\right)$ and the eastern $\left(90-110^{\circ} \mathrm{E}, 10^{\circ} \mathrm{S}-0^{\circ}\right)$ Indian Ocean. SSTs are taken from the HadISST1 data set (Rayner et al., 2003). The October-December averaged DMI over the period 1998-2014, matching with the rainfall estimates, is standardized and divided into terciles. The positive DMI composite (DMI+; i.e., warm anomalies in the west, cold anomalies in the east) correspond to the six years $(2002,2006,2011,2012,2013,2014)$ above the third tercile (DMI > 0.54), while the negative DMI composite (DMI-) includes the six years (1998, 1999, 2000, 2001, 2005, 2010) below the first tercile (DMI < -0.30). Neutral years comprise the five remaining years when the DMI is in the middle tercile. Note that given the short length of the record and the absence of highly positive dipole years (like in 1961 and 1997) in the period of study, results utilizing this index should be taken with caution. Additionally, the Niño3.4 index depicting SSTs over the equatorial Pacific Ocean is used to describe ENSO variations.

Monthly sea surface temperature fields over the period 1998-2014 are taken from the NOAA Optimum Interpolation Sea Surface Temperature (OISST) data set (Reynolds et al., 2002), at a onedegree resolution. 


\section{Methods}

The relationship between diurnal rainfall variations and both intraseasonal and interannual drivers is mainly studied by computing composite mean rainfall patterns for different phases of the drivers. Additionally, statistics such as the changes in the diurnal amplitude of the rains and their temporal phase are computed. The amplitude of diurnal variations is taken as the range between the lowest and the highest 3-hourly mean precipitation amounts. The phase is the time period which records the highest 3-hourly mean precipitation amounts. We did not find it suitable to use harmonic analysis because it supposes that diurnal regimes arise from a superimposition of smooth harmonics, and therefore, it does a poor job describing intradiurnal timing that is not sinusoidal. At Kitale in western Kenya for instance, in situ records show that as little as $1.6 \%$ of the rains fall from 0700 to 1200 local time, against $58 \%$ in the next 5 -hr period, then rainfall gradually decreases in the night (Tomsett, 1975).

Changes in the amplitude and phase of the maximum 3-hourly rainfall between DMI+ and DMI- years (warm and cold anomalies of the DMI, respectively), or between the eight different phases of the MJO, are mapped. For interannual variations, diurnal amplitude changes are based on two metrics: (i) the change in the absolute range between the mean maximum 3-hourly rainfall and the mean minimum, in mm, and (ii) the change in the contribution of mean maximum 3-hourly rainfall to mean daily rainfall, expressed as a percentage. In order to assess the effect of the MJO, several statistics are considered. The amplitude of the diurnal cycle in each of the eight MJO phases is initially computed and the maximum amplitude identified. Changes in the phase are then assessed through (i) the minimum correlation coefficient between the diurnal cycle of each MJO phase and the average diurnal cycle and (ii) the maximum phase difference (expressed in hours) across all the MJO phases. Additionally, a one-way analysis of variance (ANOVA) is carried out (for each 3-hourly time period separately, and for each grid point) to assess whether there are significant variations in the rainfall amounts recorded during the eight different MJO phases.

A cluster analysis method is designed to extract the dominant daily patterns of rainfall distribution (in space and time; i.e., during the diurnal cycle). This is carried out over eastern Kenya and southern Somalia. This subregion (Figure 1), although it records uneven precipitation amounts, shares several climatic traits (Camberlin et al., 2017; Nicholson, 1996), that is, (i) bimodal rainfall regimes (rainy seasons in MarchMay and October-December) and (ii) an afternoon rainfall maximum over land (with an apparent shift from midafternoon near the coast to late evening further inland) and a weak morning maximum over much of the Indian Ocean. The input matrix consists of all days over the 17-year time period (1998-2014), that is, 6,209 days, which are then classified into a discrete number of clusters based on both the diurnal rainfall distribution (eight bins of 3-hourly rainfall accumulation) and the spatial rainfall distribution (1,360 grid points). In all, each day is thus described by 10,880 observations $(8 \times 1,360)$.

$\mathrm{K}$-means classification is used to delineate the clusters of days. Since 0600 is the driest time of the day on average over the region, the daily sequence of observations starts at 0900 EAT. Data in $\mathrm{mm} / \mathrm{hr}$ are squareroot transformed in order to reduce the weight of heavy rainfall events (Gitau et al., 2013). As in Rauniyar and Walsh (2013), k-means is applied on nonstandardized data, using Euclidean distance as a metric. EOF prefiltering (keeping from $70 \%$ to $90 \%$ of the variance) results in very little difference in the definition of the clusters. In order to ensure the robustness of the results and to reduce the influence of the initial random draw of the clusters centroid, 50 partitions are computed and the partition retained is that which minimizes the anomaly correlation coefficient with all other partitions (Michelangeli et al., 1995). The classifiability index proposed by Michelangeli et al. (1995) is almost identical for four to seven clusters, but there is a weak peak at five clusters which indicates that this solution could be slightly more appropriate. The Elbow method (e.g., Tramblay \& Hertig, 2018) also indicates that the optimal number of clusters is 5. However, the Calinski-Harabasz criterion (Calinski \& Harabasz, 1974) failed to provide any optimal number of clusters, the index decreasing gradually with an increasing number of clusters. Based on these results and on the robustness and interpretability of the clusters, the five-cluster solution was found to be the most adequate and thus retained for analysis.

The forcing mechanisms attached to each cluster are examined as follows: (i) all days belonging to a given cluster are binned according to the eight MJO phases to detect any preferential association and (ii) interannual variations of the annual number of occurrences of each rainfall cluster are correlated with the DMI and Niño3.4 index, as well as with seasonal sea surface temperature fields. 

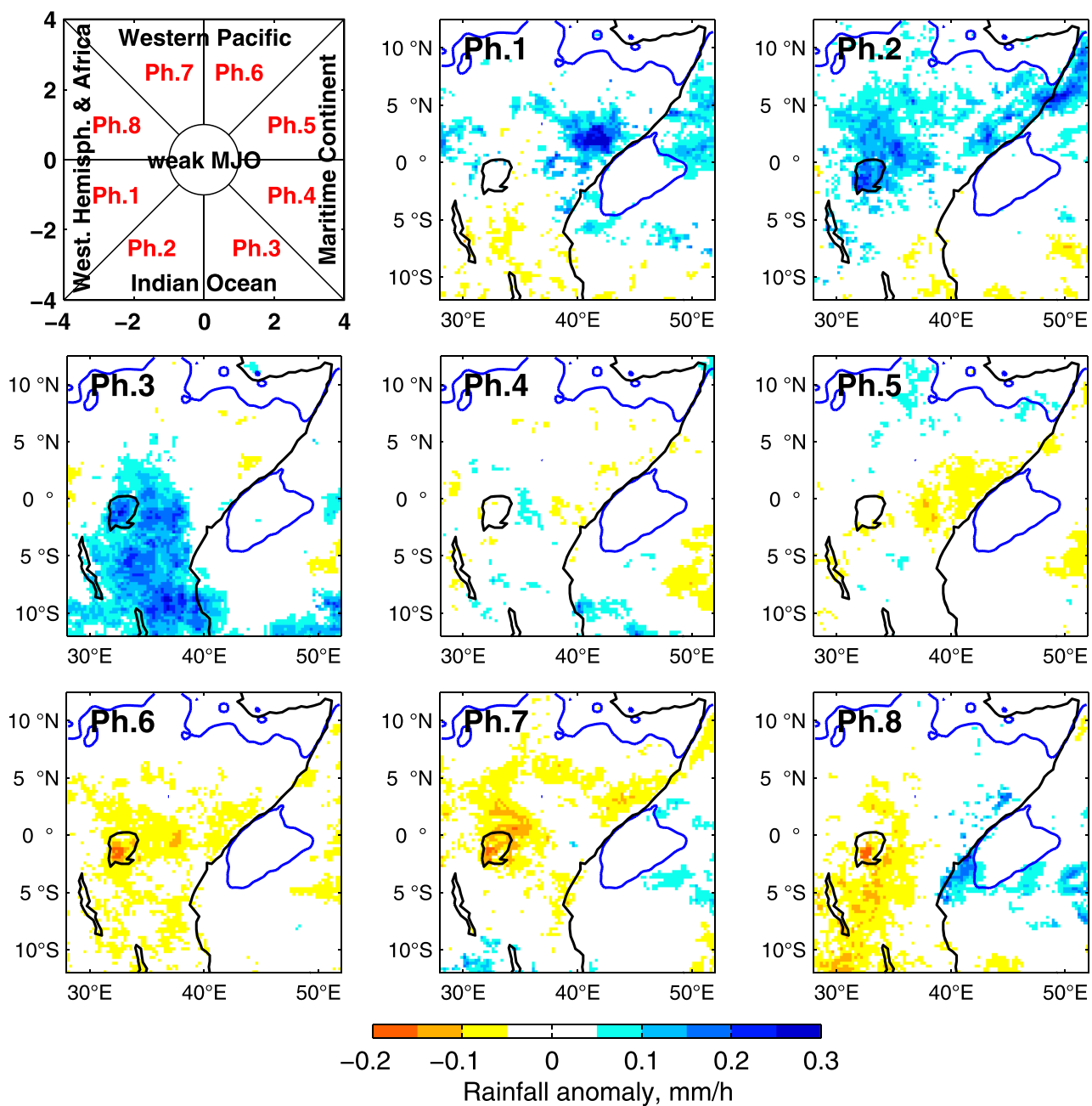

Figure 2. October-December composite rainfall anomalies for each MJO phase (RMM index). Values are anomalies relative to local rainfall average, and only days with a MJO amplitude greater than 1 are retained. Blank areas denote nonsignificant anomalies according to a one-sample Student's $t$ test $(p=0.05)$ or rainfall anomalies below $0.05 \mathrm{~mm} / \mathrm{hr}$. The dashed blue line shows the 75-mm mean OND isohyet. (top left panel) Location of global convection for each phase, after Wheeler and Hendon (2004).

\section{Intraseasonal and Interannual Modulation of the Diurnal Cycle}

The relationships between diurnal rainfall variations and both intraseasonal (MJO) and interannual (IODM) forcing mechanisms are first considered for Eastern Africa as a whole. Only the October-December season is analyzed since it is the season which shows the largest interannual variations in East Africa (Downing et al., 2008; Gitau et al., 2015) and the strongest relationship with ocean-atmosphere dynamics over the Indian Ocean.

\subsection{Changes in Diurnal Rainfall Cycle Amplitude and Phase Between MJO Phases}

Rainfall composites for each MJO phase are plotted, using the RMM index to define the phases (Figure 2). Rainfall anomalies, with respect to the seasonal mean, are positive over most of the region in phases 1 and 2 (large-scale convection between the Western Hemisphere and the Indian Ocean), with largest anomalies (>+0.2 mm/hr) in southern Somalia, Kenya, Uganda, and parts of the Indian Ocean. Positive anomalies are found earlier (phase 8) over the equatorial Indian Ocean, toward the coast of Kenya, and over parts of Somalia. This is in agreement with observations made earlier that the MJO-associated rainfall enhancement is out of phase between coastal and inland East Africa (Berhane \& Zaitchik, 2014; Hogan et al., 2015; Pohl \& Camberlin, 2006a). Large positive anomalies shift over the southern part of the region (Tanzania and 
southwestern Kenya) in phase 3. Phases 5 to 7 (large-scale convection over the MC and western Pacific) are mainly dry over equatorial Eastern Africa, with the largest negative anomalies being found from Lake Victoria to Kenya and southern Somalia. Using the OMI data, based on OLR only, similar patterns of rainfall anomalies emerge (not shown), but with a shift of about $1 / 8$ to $1 / 4$ cycle (1 to 2 phases) between RMM and OMI composites. Kiladis et al. (2014) showed that the maximum correlation between the RMM and OMI during September-November is for a four-day lag, which could partly explain these shifts.

These results confirm that there is a coherent MJO signal in the precipitation field of Eastern Africa in October-December. We now examine how the MJO projects on the diurnal cycle. Figure 3a shows the maximum variations (among the eight MJO phases) in the diurnal amplitude, expressed as a percentage of the mean rainfall amounts. Large amplitudes (300 to over 700\%) are found over most land areas, with particularly high values in Somalia, eastern Ethiopia, and eastern Kenya. Amplitudes are slightly smaller over the Indian Ocean and in the northwestern part of the region, but still exceed $150 \%$. Figures $3 \mathrm{~b}$ and $3 \mathrm{c}$ show changes in the phase using two metrics. The first one (Figure 3b) considers the minimum correlation between the diurnal cycle of each MJO phase and the average (unconditional) diurnal cycle. A high correlation means that the diurnal distribution of the rains remains stable no matter the MJO phase. A low correlation means that during at least one of the MJO phases, the diurnal distribution of the rains strongly differs from the usual distribution. There is a distinct pattern where, over land, high correlations are found near coastlines, lakes, and over mountain ranges, suggesting a very steady diurnal phase likely associated with sea, lake, and mountain breezes. By contrast, lowland areas away from coastlines (e.g., Lake Turkana corridor between Ethiopia and Kenya), or plateau areas (e.g., central Tanzania), as well as the Indian Ocean display low correlations which means that during at least of one of the MJO phases, the diurnal distribution of the rains is strongly disturbed. Figure $3 c$ uses another criterion to display phase changes, the maximum absolute difference in the peak time of the rains across the eight MJO phases. The spatial pattern is almost the same as in Figure 3b, indicating consistency in the effect of MJO on diurnal rainfall phasing. In many regions, a maximum phase shift of $12 \mathrm{hr}$ can be found in the diurnal maximum. Some of these regions (for instance much of the Indian Ocean; Figure 3a) also display a small amplitude in their diurnal cycle, which in this case merely suggests an overall weak response to the MJO. However, there are land regions (like northern Kenya, eastern Ethiopia, parts of inland Tanzania) where a large phase shift is found, whereas the amplitude of the diurnal cycle is also high. In these cases, the phase shift may be interpreted as a climatic signal associated with the MJO. Note that over arid areas (encompassed by a pink dashed line in Figures $3 \mathrm{a}$ and $3 \mathrm{c}$ ), the high amplitude and apparent large phase shifts should be taken with caution since the rare rainfall occurrence renders statistics on the role of MJO not very robust, with a possible total absence of rain during some phases.

As a complement, an analysis of variance is carried out to test the dependency of rainfall over each 3-hr period to the MJO phases. Figure 4a displays the number of periods in a day (out of 8) that rainfall amounts depend significantly on the MJO phases. RMM is used to describe the MJO, but quite similar results are obtained with the OMI, albeit less significant (not shown). Over most of Kenya, eastern Uganda, central Tanzania, southern Somalia, and parts of the Indian Ocean (especially near the coast of Kenya), at least half of the 3-hr periods have their precipitation amounts significantly modulated $(p=0.05)$ by the MJO.

Three subregions are selected (red boxes in Figure 4a) to show how diurnal regimes are modified by the MJO. Over the Indian Ocean off the Kenya Coast, rainfall is low during the OND season. Diurnal variations are weak and rain can occur at any time, although rainfall tends to peak in the morning (Figure $4 \mathrm{~b}$ ). The most obvious change is for phases 8 and 1, where a general enhancement by about a factor of 2 in rainfall is found. The daytime concentration remains, with a main peak at 0600-0900 EAT and a secondary one at 1500. Other MJO phases are not clearly differentiated from each other, and there is no obvious shift in the time of the peak rainfall. Other Indian Ocean areas (not shown) display quite unsteady phases of peak rainfall, mainly due to the overall weakness of their diurnal cycles.

In the Kenya Highlands subregion (Figure 4c), there is a clear rainfall minimum at 1200 EAT, and the diurnal cycle strongly peaks shortly afterward (1500 or 1800), with a slow decline thereafter. It is mainly the intensity of the afternoon peak and its duration which are affected by the MJO. Phases 2 and 3 show the highest afternoon rainfall and phase 7 the lowest. There is also evidence of longer-lasting wet conditions at night in phases 2 and 3. Between MJO phases 2 and 7, that is, when convective activity associated with 
(a) Max. relative amplitude of diurnal cycle across all MJO phases (\% mean precipitation)

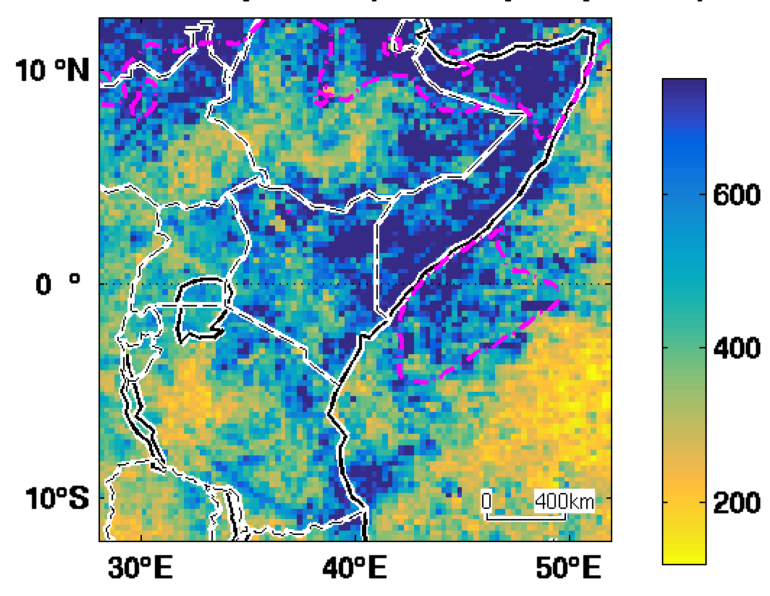

(b) Min. correlation between diurnal cycle of each MJO phase and ave. diurnal cycle

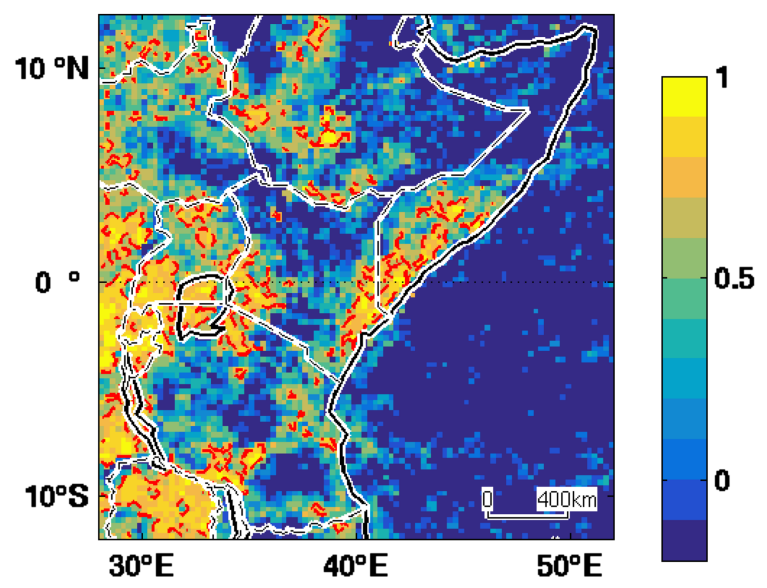

(c) Max. phase difference (hrs) across all MJO phases

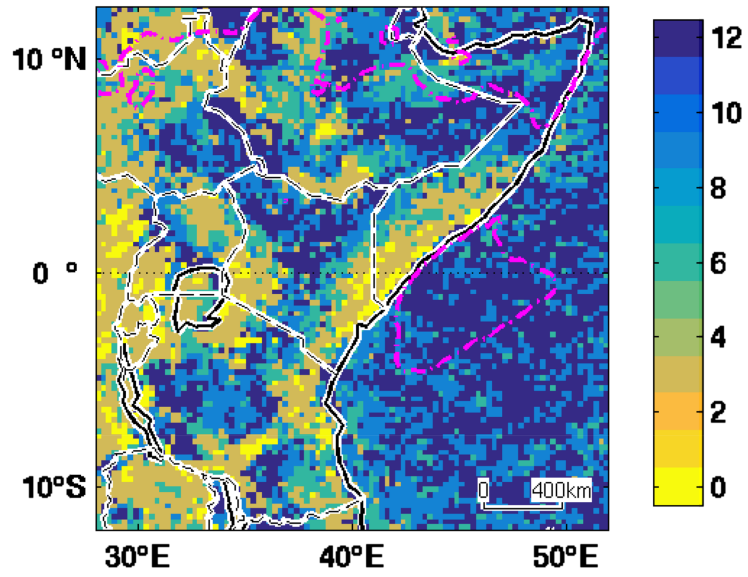

Figure 3. Statistics on changes in the October-December diurnal rainfall cycles associated with the different MJO phases. (a) Maximum relative amplitude of the diurnal cycle among the eight MJO phases, as a percentage of mean precipitation. (b) Minimum correlation coefficient between the diurnal cycle of each MJO phase and the average diurnal cycle, with significant values ( $p=0.05$ ) enclosed by red dashed lines. (c) Maximum absolute phase difference (in hours) between all the MJO phases. The pink dashed lines in (a) and (c) show the 75-mm mean OND isohyet. 
(a) ANOVA, nb of 3-hr periods modulated by MJO $(\mathrm{p}=0.05)$

(b) Indian Ocean diurnal regimes

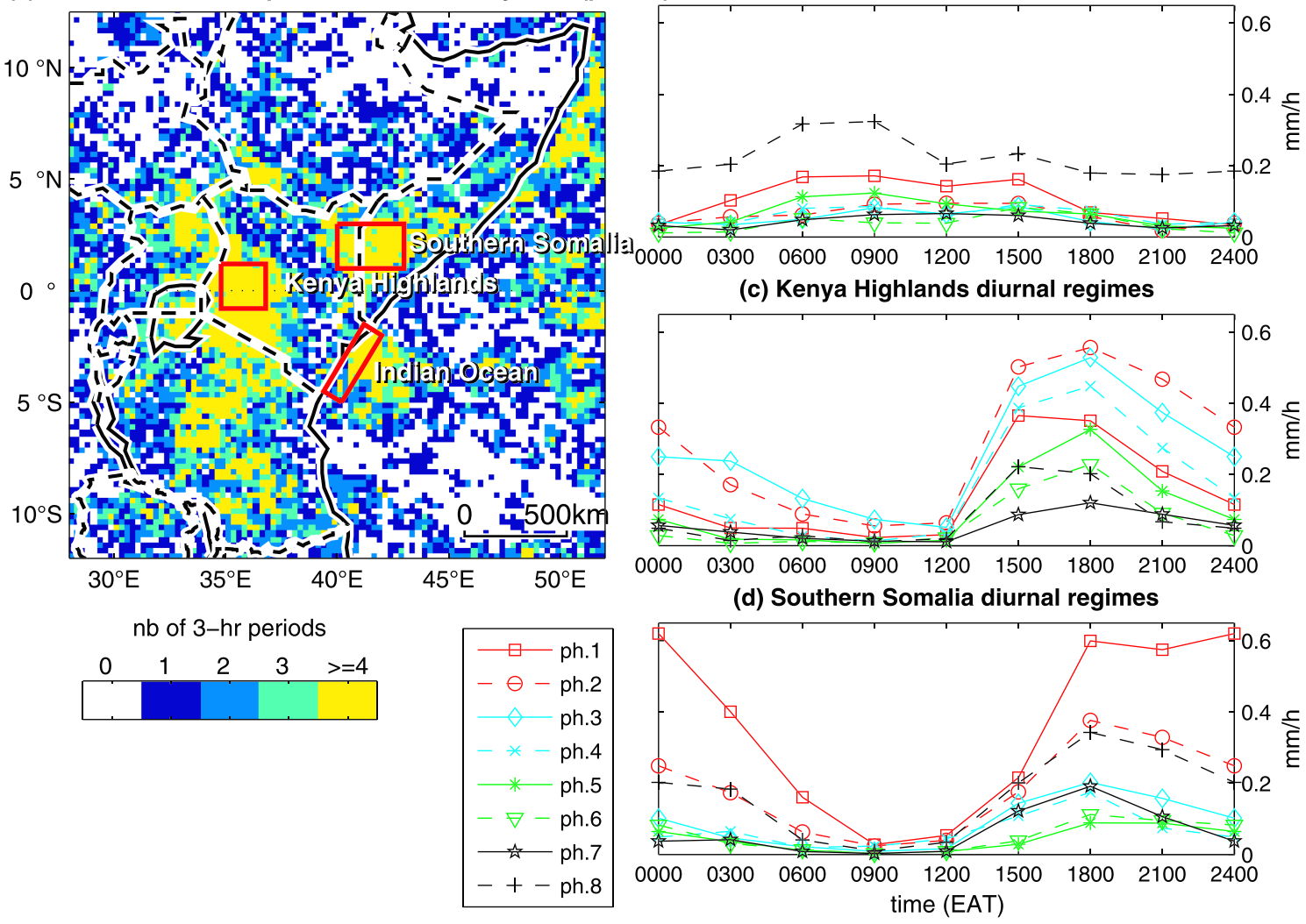

Figure 4. Modulation of October-December diurnal rainfall variations by the MJO (RMM index). (a) Result of ANOVA on the changes in precipitation amounts associated with MJO phases, by 3-hr periods, expressed as the number of 3-hr periods (out of 8) over which rainfall is significantly ( $p=0.05$ ) modulated by the MJO. (b-d) Mean diurnal rainfall variations associated with each MJO phase over three East African subregions as shown by the red boxes in (a).

the MJO gradually declines, there is a slight delay in the timing of highest rainfall (1800 instead of 1500). However, the overall phasing of the rains displays little variations, as shown earlier in Figure 3a.

Southern Somalia (Figure 4d) also shows large changes between the various phases, again essentially with respect to the amplitude of the cycle and duration of the rain spell. The wettest MJO phase is phase 1, in contrast with the Indian Ocean (phase 8) and the Highlands (phase 2). A reduction of rainfall amounts by a factor of six occurs in phases 5 and 6 (see also Figure 3a). Mornings are dry regardless of the MJO phase, and the rainfall shows a late afternoon peak at 1800 in all phases. Relatively heavy rainfall occurs later at night in phases 8 to 2 , the main maximum being even shifted to 2400 during phase 1 .

When considering all the land pixels together, it is found that the frequency distribution of the timing of the diurnal rainfall maximum changes little from one MJO phase to another (see Supporting information S1). About $35 \%$ of the land pixels have their rainfall maximum at 1800 whatever the MJO phase. This frequency is only slightly lower during MJO phases 1 and 2 (mostly wet in Eastern Africa), during which the frequency of nighttime peaks marginally increases. Inversely, the 1800 peak is a bit more frequent during the quiescent phases 5 and 6 (mostly dry over Eastern Africa). Over the Indian Ocean, the timing of the rainfall maximum is more inconsistent. As discussed above, morning peaks tend to dominate, but about $15 \%$ of the pixels have their maxima in the afternoon (1500). Some discrepancies exist between the different phases of the MJO, but these changes are not meaningful since phase patterns over the ocean are very noisy (Figure 1).

On the whole, the MJO has a strong impact on OND rainfall variations in the region, but the modulation of the diurnal cycle seems to be mainly via its amplitude and secondarily the lengthening of the diurnal peak, rather than via any major change in the timing of the wettest hours, at least over land. This is in contrast with Sakaeda et al. (2017), who found a delay in the diurnal phase of about $3 \mathrm{hr}$ within the MJO and other 


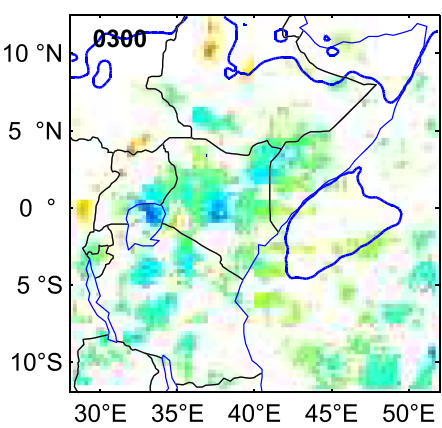

$\mathrm{DMl}+$ minus DMI-
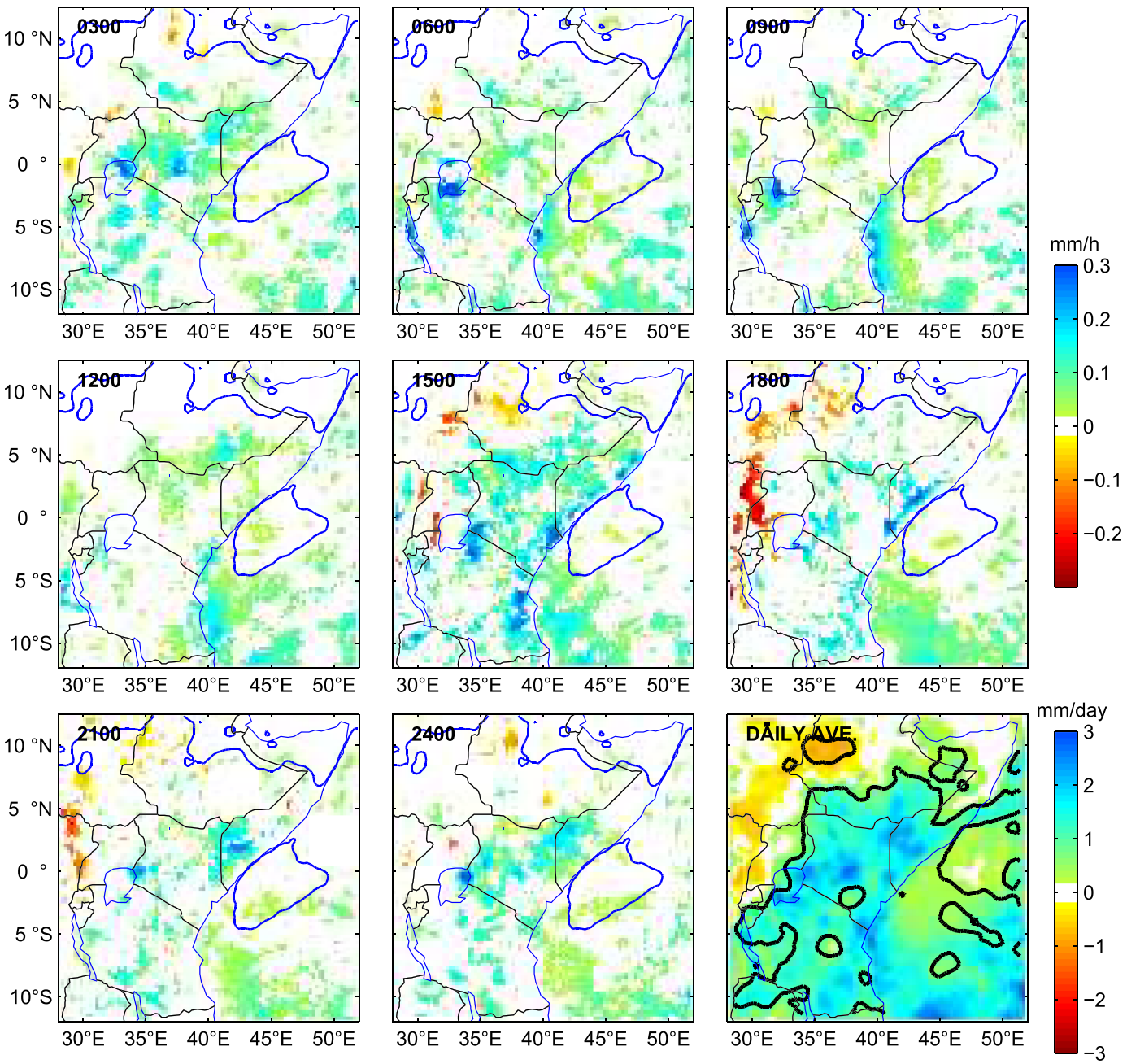

Figure 5. (bottom right panel) Difference between October-December precipitation amounts in high and low DMI years, for each 3-hr period (in $\mathrm{mm} / \mathrm{hr}$ ) and for the whole day ( $\mathrm{mm} /$ day). In the 3-hourly panels, blank areas denote nonsignificant differences according to a two-sample Student's $t$ test $(p=0.05)$, and the dashed blue lines show the 75-mm mean OND isohyet. For the daily average, significant values $(p=0.05)$ are bounded by black lines

equatorial waves over the west Pacific warm pool. In order to take into account the actual cycle of individual rain systems, an alternative method was used to study the relationship with the MJO in section 6 .

\subsection{Changes in Diurnal Rainfall Cycle Amplitude and Phase Between Opposite Phases of the IODM}

Interannual variations in 3-hourly rainfall distribution are investigated next, again for October-December. Composite 3-hourly rainfall averages are computed for low and high DMI years, respectively, and the difference plotted in Figure 5, which also displays the difference for the daily precipitation mean (Figure 5, bottom right).

The daily average confirms the higher rainfall observed across most of Eastern Africa in high DMI years, as noted by previous authors. Large, significant differences (1-3 mm/day; i.e., about 90-270 $\mathrm{mm}$ for the whole season) are found over Kenya, southern Somalia, much of Tanzania, and large parts of the Indian Ocean, especially near the coast of Kenya. The northwestern areas (western Ethiopia, South Sudan, DRC-Uganda border) tend to depart from the rest of the region, showing lower rainfall in DMI+ years. At the subdaily time scale, positive values strongly dominate across Eastern Africa, whatever the time of the day. Significant differences between DMI+ and DMI- years are found 
along the Indian Ocean coast at the time of the main rainfall peak, both offshore (morning maximum) and inland (afternoon maximum). Many other equatorial land areas display positive differences between high and low DMI years at the time of their main rainfall peak, like the Kenya Highlands (from 1500 to 0300 EAT) or southern Somalia (1800 to 2400). Despite having an inverted diurnal cycle (early morning maximum), Lake Victoria also records higher rainfall during positive dipole mode events. The lower rainfall found in high DMI years in some of the westernmost areas, contrary to most parts of Eastern Africa, corresponds to reduced convective activity in the afternoon and evening (1500 to 2100). Isolated areas, like to the northwest of Lake Victoria, show both reduced rainfall (e.g., around 1800) and increased rainfall (e.g., around 0600) depending on the time of the day.

Figure 6 summarizes the changes in the diurnal cycle between high and low DMI years, expressed in terms of amplitude (difference in rainfall amounts between wettest and driest 3-hr periods), phase (change in the timing of the wettest 3-hr period), and contribution of peak rainfall to the rainfall total (change in the percentage rainfall amount recorded during the wettest 3-hr period). During positive dipole mode events, there is an overwhelming increase in the amplitude of the diurnal cycle (Figure 6a) over most land areas (northeast Uganda, southern Ethiopia, southern Somalia, Kenya, and Tanzania) as well as over the Indian Ocean. The increased amplitude is mainly due to higher rainfall during the diurnal peak since in general rainfall differs little between DMI+ and DMI- at the driest time of the day. However, the amplitude is reduced from the west of Lake Victoria to eastern DRC, southern Sudan, and western Ethiopia. This is in line with the fact that positive IODM events result in abnormally dry conditions over these regions, contrary to most of Eastern Africa (Figure 5).

Over the continent, the phase (Figure 6b) is often unchanged, or sometimes shifts by a few hours between the two categories of years, not in a very consistent way. In a majority of cases the peak rainfall occurs slightly ahead ( $-3 \mathrm{hr}$ ) in DMI+ years compared to DMI-. Although along the coast the phase is unchanged, occasionally positive values occur at a certain distance inland, like over northeastern Kenya, denoting a delay in the rainfall phase in high DMI years of up to 5 to $10 \mathrm{hr}$ at about 500-600 km from the coast, which will be further studied below. Big positive lags are also found further south in central Tanzania. The patchy pattern found over the Indian Ocean is indicative of the fact that the diurnal variations are small over the ocean. Some patchiness is also found over northern Somalia and eastern Ethiopia, which is related to the dry climate of these regions, making diurnal regimes quite unstable.

The change in the contribution of peak rainfall to the rainfall total between the two types of years (Figure 6c) is generally small, confirming that it is the overall rainfall amount which is increased in high DMI years. Some areas show a marked reduction ( $-5 \%$ or less), like in parts of Somalia, suggesting that the rains are more evenly distributed throughout the day in DMI+ years, although the rainfall peak is enhanced, but the pattern is noisy and statistical significance is reached only locally.

In order to further explore the changes in diurnal rainfall variations, area-averaged indices are extracted for a few subregions delineated in Figure 6a. For display purposes, the diurnal cycle is resampled at a 1-hr time step by fitting a cubic spline to the 3-hourly data. High and low DMI years are significantly different in each subregion (Figure 7). Neutral years generally stand between positive and negative years, although closer to the latter, in agreement with the fact that positive Indian Ocean Dipole Mode events result into much larger Eastern Africa rainfall anomalies than negative IODM events do (Black et al., 2003).

The Western Kenya Highlands (Figure 7a) illustrate cases where the influence of the IODM is merely an enhancement of the diurnal cycle in high DMI years, affecting all time periods from midafternoon to the late night ( $+0.1 \mathrm{~mm} / \mathrm{hr}$ compared to low DMI years; i.e., around $+130 \mathrm{~mm}$ in the whole season). Mornings remain very dry, and rainfall swiftly increases in the early afternoon until the strong late afternoon peak (1800 EAT), which incurs little phase shift between the different categories of years.

Lake Victoria (Figure 7b) clearly shows its characteristic inverted diurnal cycle, with a morning peak in both high and low DMI years, related to land breeze convergence in the middle of the lake at nighttime and in the morning (Anyah et al., 2006; Flohn \& Fraedrich, 1966). This is followed by dry conditions in the afternoon (irrespective of the IODM phase) due to lake breezes and associated divergence over the lake. As in the Kenya Highlands, in positive DMI years the precipitation amount is higher, and the phase is only marginally affected, with the peak being slightly earlier than in negative DMI years. 
(a) amplitude of diurnal cycle, DMI+ minus DMI-

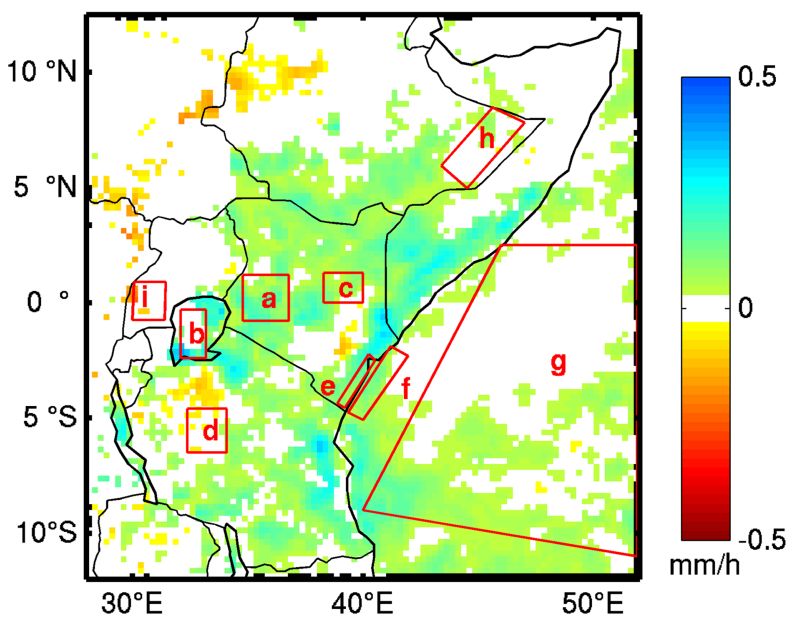

(b) phase of diurnal max., DMI+ minus DMI-

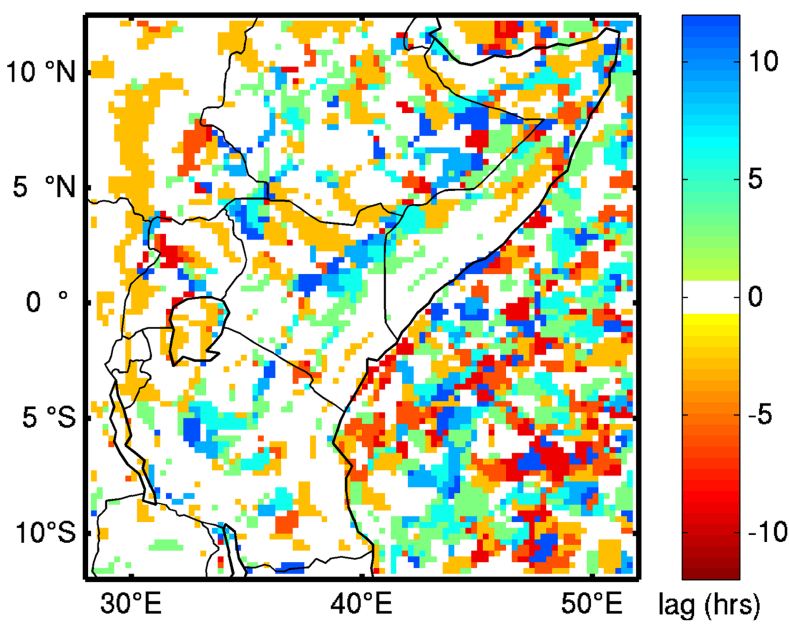

(c) contribution of peak rainfall to total, $\mathrm{DMI}+$ minus $\mathrm{DMI}-$
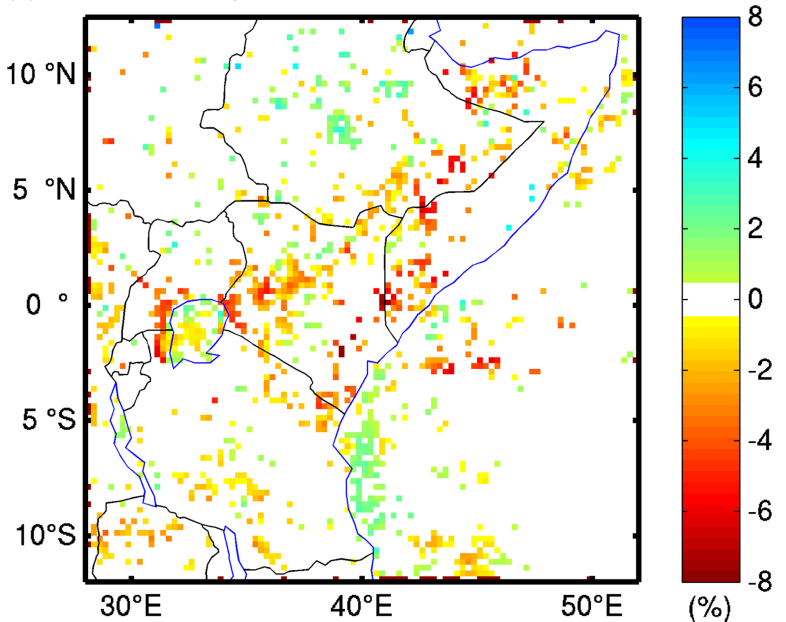

Figure 6. Difference in October-December precipitation between positive and negative DMI years. (top) Amplitude of the diurnal cycle. (middle) Phase difference (in hours) between the diurnal rainfall peak in positive and negative DMI years. Positive values indicate that the rainfall maximum is found later in DMI+ years. (bottom) Percentage contribution of 3-hr maximum rainfall to total rainfall. Plot (a) also shows the location of the subregions plotted in Figure 7. In (a) and (c), only the differences statistically significant at $p=0.05$ (Student's $t$ test) are shown. 
(a) Western Kenya Highlands

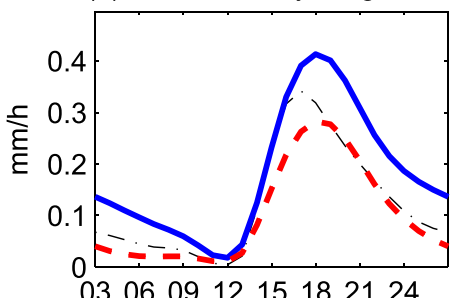

(d) Central Tanzania

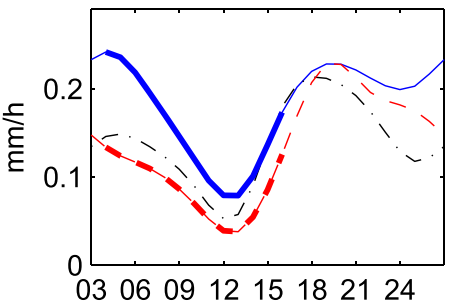

(g) Indian Ocean

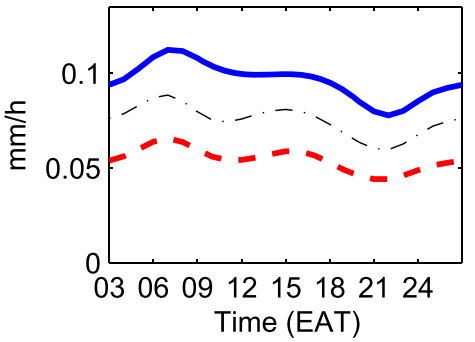

(b) Lake Victoria

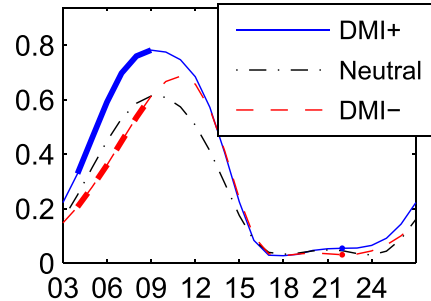

(e) Kenya Coast

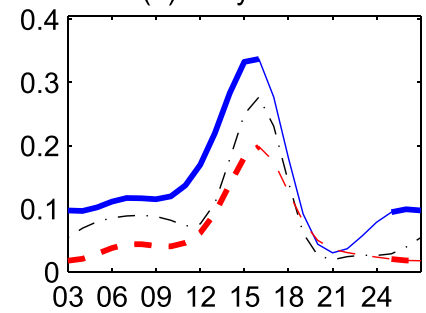

(h) Ogaden

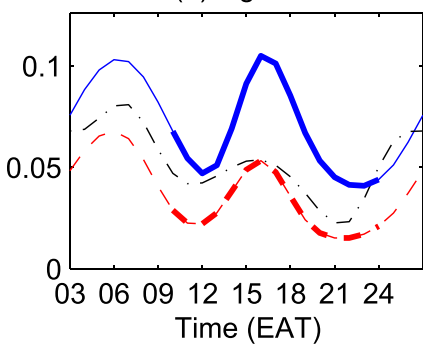

(c) Northeastern Kenya

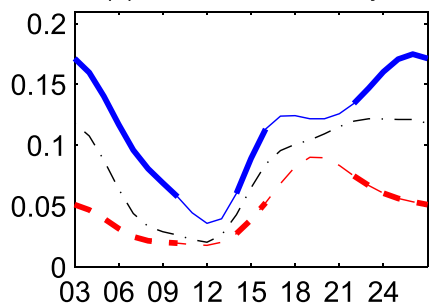

(f) Indian Ocean off Kenya

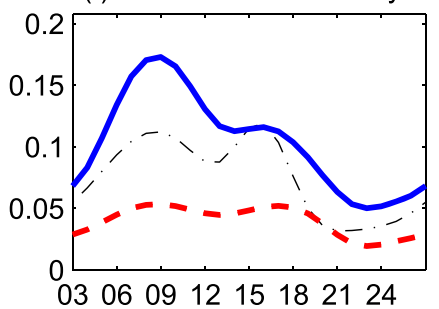

(i) Southwestern Uganda

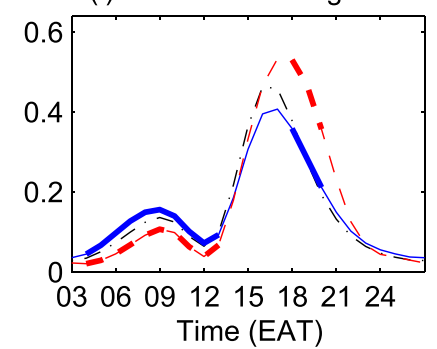

Figure 7. Mean diurnal cycles of October-December rainfall averaged over the Eastern Africa subregions shown in Figure 6a, for positive, neutral, and negative phases of the Indian Ocean Dipole Mode (in $\mathrm{mm} / \mathrm{hr}$ ). Thick lines: difference between DMI+ and DMI- years significant at $p<0.05$ ( $t$ test).

Northeastern Kenya (Figure 7c) and central Tanzania (Figure 7d) show patterns quite different from the above ones. In high DMI years, there is a main peak at nighttime (0000 to 0300 EAT and 0300 to 0600). A late afternoon secondary peak is also found at both locations (about 1700 in northeastern Kenya and 1900 in central Tanzania). It is conspicuous that while the low DMI years show lower precipitation almost throughout the day, the nighttime maximum vanishes, making the late afternoon the wettest time of the day. This accounts for the large positive lead time ( 5 to $10 \mathrm{hr}$ ) in diurnal phases found over these regions in Figure 6. It is suggested that the late afternoon maximum reflects local convection, while the nighttime maxima reflect travelling disturbances and/or lowland night convergence associated with katabatic flows. We speculate that while daytime convection is activated in positive DMI years, locally boosting the late afternoon peak, the convective cells then last longer and travel longer distances, reaching areas where they seldom occur in DMI- years such as northeastern Kenya and central Tanzania, and resulting in a second peak at night (possibly becoming the dominant one). In northeastern Kenya, these long-lived rain cells might originate from the coastal regions, as suggested by the mean rainfall phase being gradually delayed from the Indian Ocean coast to the interior (Figure 1). Inversely in negative DMI years, the absence of long-lasting disturbances would explain the strongly reduced nighttime precipitation.

Along the coast of Kenya, two regimes were identified, the first one on the land part and the second one over the Indian Ocean. The land index (Figure 7e) exhibits a distinct early afternoon peak, as a result of convection along the sea breeze front. The inland shift of convective cells and subsequent replacement by cooler air resulted in dry evenings. In positive DMI years, there is mostly a general enhancement of the rains (at all times of the day except in the evening). Over the Indian Ocean off the Kenyan coast (Figure 7f), the diurnal regimes are not well defined, showing weak peaks in the afternoon and the early morning. There is a general rainfall enhancement in high DMI years, but relatively larger for the morning maximum $(+200 \%)$ than the 
(a) $\mathrm{DMI}+$

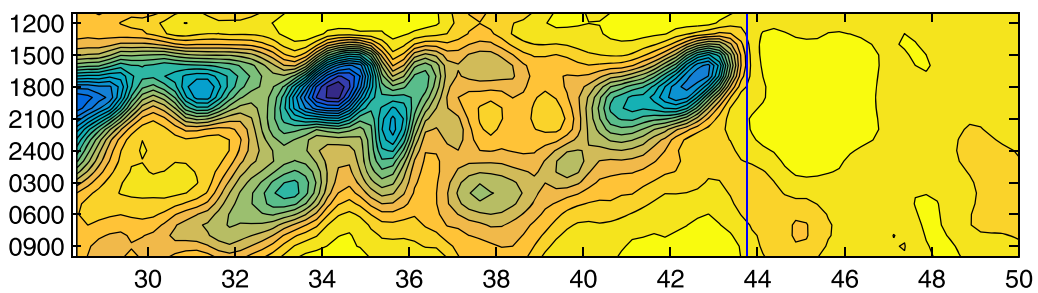

(b) DMI-
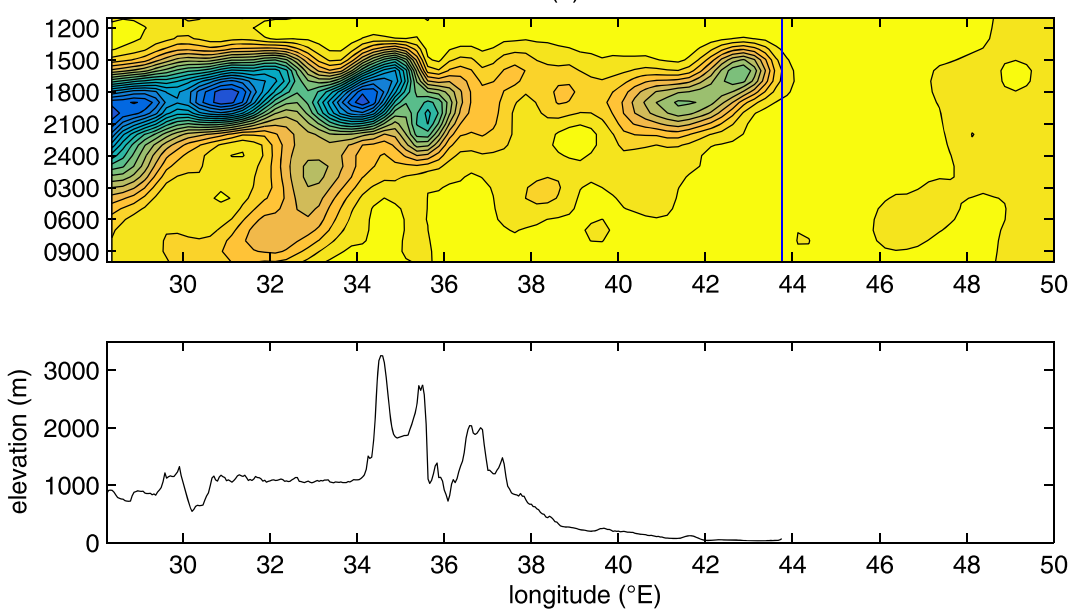

$\mathrm{mm} / \mathrm{h}$

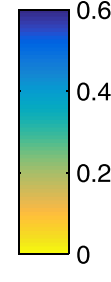

$\mathrm{mm} / \mathrm{h}$

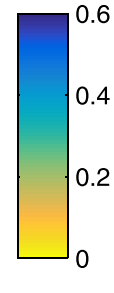

(c)

Figure 8. Time $\times$ longitude plots of mean hourly October-December rainfall distribution from 28.5 to $50^{\circ} \mathrm{E}$, along latitude $1^{\circ} \mathrm{N}$ : (a) average of positive DMI years, (b) negative DMI years, and (c) elevation along the cross section. Vertical bars in (a) and (b) denote the coastline.

afternoon one (+100\%). The morning peak becomes prominent in DMI+ years, while the two peaks are more balanced in neutral and DMI- years. The early morning maximum close to the coast is likely associated with convergence between large-scale winds (easterlies) and the land breeze. During positive IODM events, while anomalous equatorial easterlies are known to occur over the equatorial Indian Ocean (Hastenrath et al., 1993), the land breeze could be enhanced by the warmer sea surface. Moist convection associated with the convergence may also be enhanced as a result of increased atmospheric moisture content over the warmer Indian Ocean. Further offshore (Figure 7g), the regimes display a similar semidiurnal cycle, but the changes between the three categories of years show up merely as a general enhancement/reduction of rainfall intensity, approximately constant throughout the day. Quite a similar response to the IODM is found over the dry Ogaden region in eastern Ethiopia (Figure 7h), with its double-peak diurnal regimes (maxima around 1600 and 0600).

Finally, southwestern Uganda, located West of Lake Victoria, stands out by showing more rainfall in low DMI years (Figures 6 and 7i). The diurnal regimes interestingly show that local afternoon convection is actually slightly stronger in DMI- years. However, the weak morning peak, probably associated with remnants of convective cells developed over Lake Victoria, is reduced in DMI- years, like over the lake itself. Two hypotheses can be proposed to explain these contrasted patterns: (i) at regional scale, a shift of the meridional arm of the ITCZ, moving eastwards in DMI+ as a result of the warmer Indian Ocean (hence a bit drier conditions in the westernmost part of Eastern Africa), and (ii) at mesoscale, a negative feedback loop, whereby enhanced nighttime convection over Lake Victoria may deplete atmospheric moisture. With the onset of the lake breeze during the day, the westward-advected airmass would be drier, which is detrimental to afternoon convection. These hypotheses are further examined in Figure 8.

Time-longitude plots near the equator $\left(1^{\circ} \mathrm{N}\right)$ are constructed to show the relationship between relief and diurnal rainfall variations during positive and negative IODM events (Figure 8). Very clear late afternoon convective maxima are found on the leeside (west) of mountain ranges, as well as west of the coastline. East of $32^{\circ} \mathrm{E}$, rainfall during positive DMI years is systematically enhanced (over both land and ocean, 
and at any time of the day). Another difference between the two samples of years lies in the duration of the rain systems generated from afternoon convection. For instance, there is an apparent propagation of the rain cells from the coastal belt (maximum around 1500-1800 EAT at $43^{\circ} \mathrm{E}$ ) toward the interior (maximum around $0300-0600$ at $38^{\circ} \mathrm{E}$ ), which (at least initially) reflects the sea-breeze penetration. This propagation is strongly reduced in negative DMI years. This is in line with the above hypotheses on the contrasted nighttime rainfall patterns found in northeastern Kenya (Figure 7c), where precipitation peaks at night during positive DMI years, overwhelming the local late afternoon showers.

West of $32^{\circ} \mathrm{E}$, there tends to be a rainfall enhancement during relatively drier periods of the day in positive DMI years, but the dominant afternoon peak is by contrast less well defined than in negative DMI years (Figure 8a-b). This accounts for the reduced amplitude of the diurnal cycle in DMI+ in the westernmost regions (Figure 6). To explain the slightly less intense precipitation during late afternoon hours in positive DMI years (at odds with the general pattern over Eastern Africa), it is speculated that daytime heating could be reduced in these years due to extensive cloud cover resulting from the longer-lasting convective systems developed the day before further east. Additionally, atmospheric moisture depletion due to the longerlasting and more intense convective systems would result in the dry airmass being advected westward by the easterly winds and resulting in less convective activity west of $32^{\circ} \mathrm{E}$ (Figure 8a).

\section{Main Space-Time Diurnal Patterns and Their Modulation}

In this section, an alternative approach is proposed which considers daily variations in the diurnal and spatial distribution of the rains, as a way to better reflect actual rain cells and their propagation. A clustering of days is first developed. The results are then discussed to see how much they are constrained by intraseasonal (MJO) and interannual (IOD) variability. The analysis is carried out over the Kenya/southern Somalia subregion (Figure 1), over the whole year. Note that this region is different from the smaller boxes defined in section 5.1 .

\subsection{Clustering of Diurnal Patterns Over Kenya and Somalia}

The results of the k-means clustering are shown in Figures 9 and 10. Each cluster is described by eight maps showing the 3-hourly rainfall distribution as an average of all days comprised in the cluster (Figure 9). Statistics on the monthly occurrence and interannual variations of each cluster are in Figure 10. Cluster 1 depicts virtually dry days over the whole area or highly localized rainfall events. As expected in semiarid environments (Crétat et al., 2012), it regroups the greatest number of days ( $81 \%$ of the 6,209 days), with more days during the driest months (January-February and July-August; Figure 10). However, there are still large numbers of such days during the rainy seasons. For March-June (MAMJ) and September-December (SOND), about 20 to $30 \%$ of the days belong to this cluster.

Cluster 2 aggregates rainfall events which mainly impact the Indian Ocean, with an extension over the coastal region (Figure 9). They are mostly stationary, with rainfall amounts similar for all the 3-hr periods, although some enhancement is found close to the coast of Kenya in the morning, slightly extending inland in the early afternoon. These events strongly peak in the April-June season, the rainiest season on the Kenya Coast (Camberlin \& Planchon, 1997). There are few events in SOND except in some years like 2006 and 2009.

The next three clusters are associated with rainfall over the continent. They show strong similarities in the diurnal cycle and mostly differ by their location and intensity. Cluster 3 (Figure 9) shows wet events over southern Somalia. Rain cells develop at 1500 EAT at a distance of about 50-80 km from the coastline. The cells then propagate and extend toward the interior (around 200-250 km from the coastline at 2100), then gradually decay during the night. This pattern and the diurnal propagation suggest that these events are related to sea breeze penetration and convective activity along the breeze front. They have a clear bimodal distribution with most events in April-May and October-November (Figure 10), the two rainy seasons in southern Somalia. Small interannual variations of these events are found in MAMJ, although a significant trend ( $p=0.05$ ) toward an increasing frequency between 1998 and 2014 is evident. SOND shows much larger interannual variations.

Cluster 4 is quite similar to cluster 3 but for southern Kenya. It shows a propagation of rain cells from an area close to the coastline at 1500 toward the Kenya Highlands, where the more intense rainfall is observed in the middle of the night (0000 to 0300; Figure 9). The westward moving cells actually merge with and bolster local 

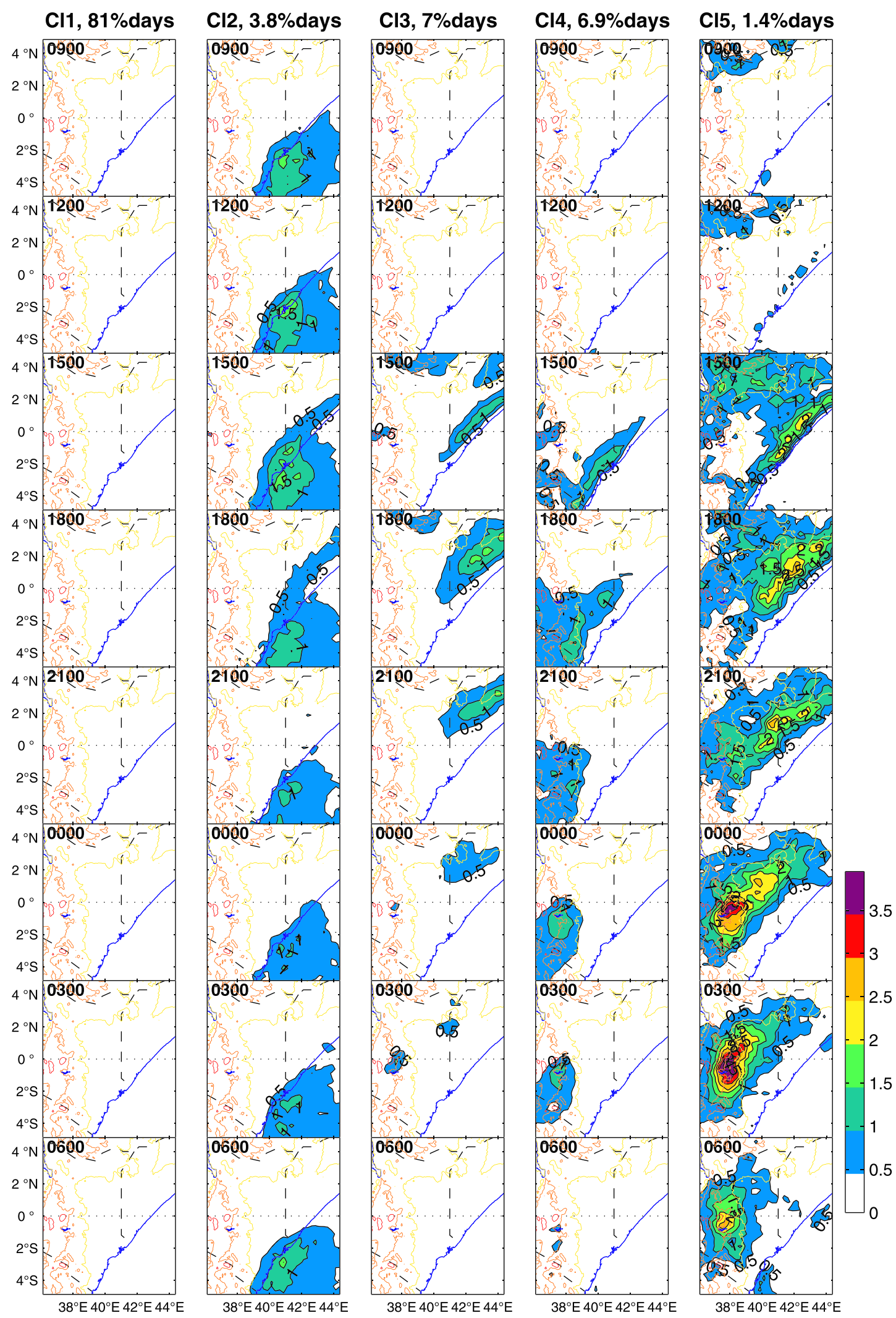

Figure 9. Spatial patterns of the cluster analysis of space-time rainfall distribution over the Kenya/southern Somalia subregion. Each plot shows mean 3-hr rainfall in $\mathrm{mm} / \mathrm{hr}$ for each cluster. Elevation contours are shown in yellow (400 m), brown (1,200 m), and red (2,500 m). 
Cluster $1,81 \%$ days, $0.55 \mathrm{~mm} /$ day

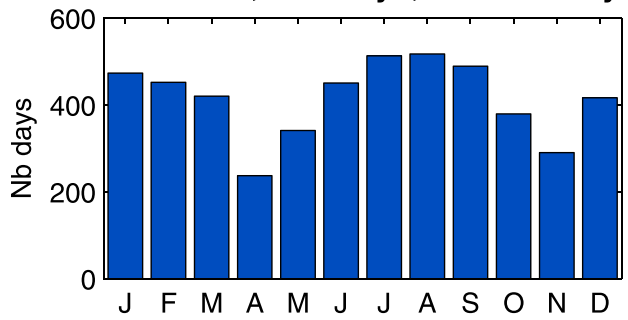

Cluster 2, 3.8\%days, $6.7 \mathrm{~mm} /$ day

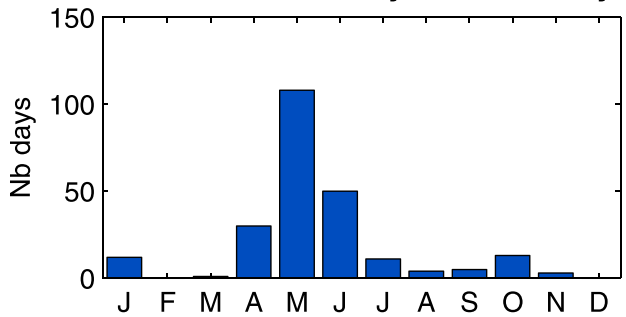

Cluster 3, $7 \%$ days, $4 \mathrm{~mm} /$ day

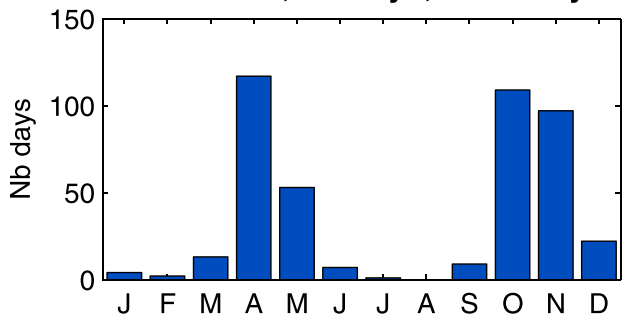

Cluster $4,6.9 \%$ days, $4.2 \mathrm{~mm} /$ day

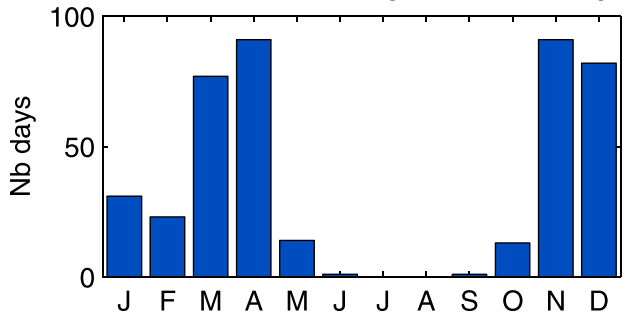

Cluster $5,1.4 \%$ days, $12 \mathrm{~mm} /$ day

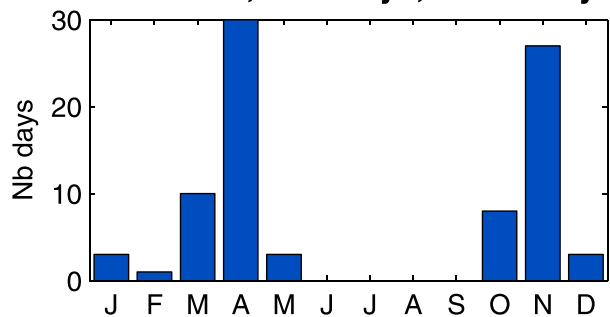

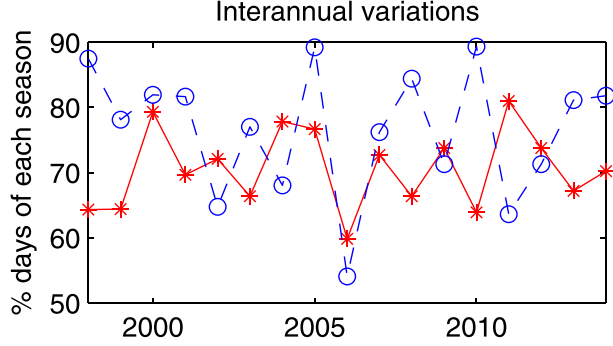
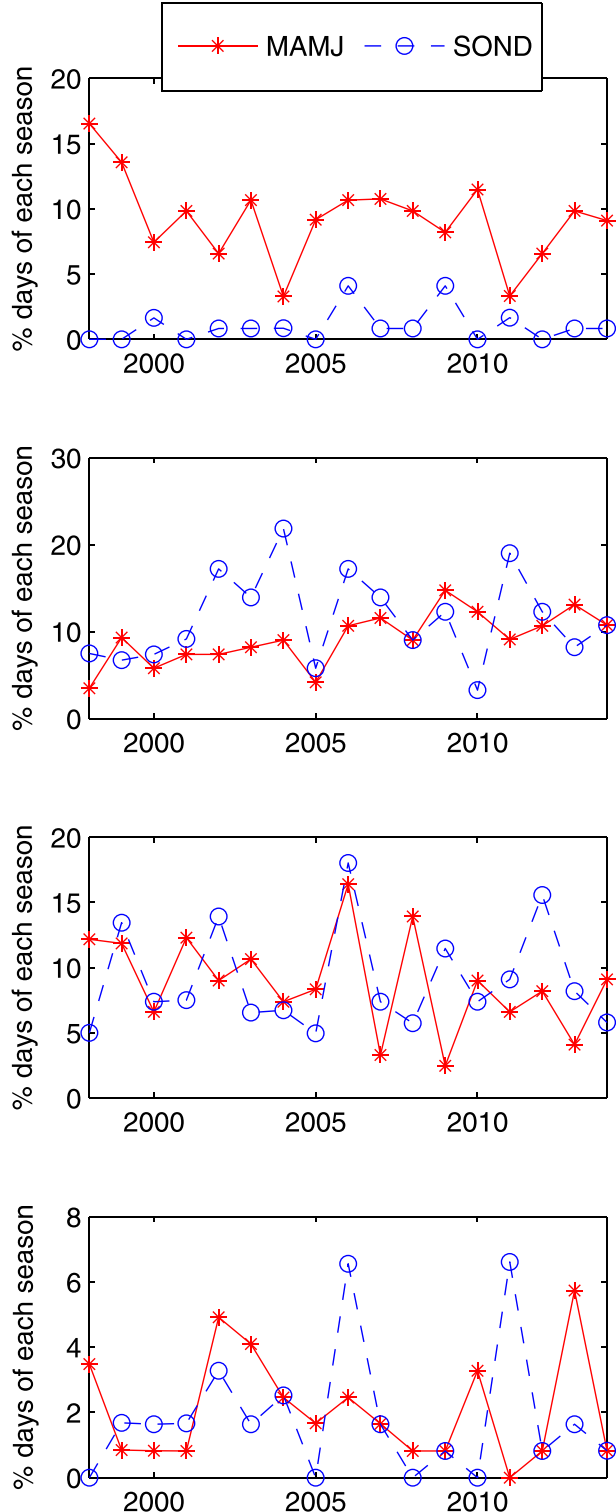

Figure 10. Temporal variations of the rainfall clusters for the Kenya/southern Somalia subregion. (left panels) Monthly number of events by cluster (the overall percentage of days and the regional mean rainfall in mm/day are provided on top). (right panels) Interannual variations in the percentage of days of each season classified in a given cluster for March-June (MAMJ) and September-December (SOND).

convection developed inland over high ground areas between 1500 and 1800. A bimodal annual cycle prevails with peaks in March-April and November-December, consistent with the mean rainfall regimes in southern Kenya. Large interannual variations in the frequency of this pattern are found in both seasons. Contrasting to cluster 3 , a significant decreasing trend $(p=0.05)$ is found for cluster 4 during MAMJ, 
Table 1

Percentage Number of Days of Each Rainfall Cluster According to the Eight MJO Phases (RMM Definition; Wheeler \& Hendon, 2004)

\begin{tabular}{lccccccccc}
\hline$\%$ & \multicolumn{1}{l}{ RMM MJO PHASE $($ ays with amplitude $>1$ ) } \\
\hline Cluster & 1 & 2 & 3 & 4 & 5 & 6 & 7 & 8 & All \\
\hline 1 & 13.4 & 13.4 & 9.5 & 11.5 & 14.9 & 14.1 & 11.4 & 11.7 & 100 \\
2 & 26.7 & 15.5 & 5.0 & 4.3 & 3.7 & 11.8 & 15.5 & 17.4 & 100 \\
3 & 17.3 & 16.1 & 12.5 & 12.5 & 11.7 & 9.7 & 6.9 & 13.3 & 100 \\
4 & 8.4 & 16.1 & 28.7 & 18.8 & 8.8 & 5.4 & 6.5 & 7.3 & 100 \\
5 & 15.4 & 25.0 & 26.9 & 11.5 & 9.6 & $\mathbf{0 . 0}$ & $\mathbf{3 . 8}$ & 7.7 & 100
\end{tabular}

Note. Only days with a MJO amplitude greater than 1 are retained. All months combined. Light (heavy) shading denotes values above $15 \%$ (25\%), and bold figures below $5 \%$. suggesting a shift from Kenya to southern Somalia in the center of gravity of the diurnal cells developed near the coast.

Finally, cluster 5 aggregates a small number (85) of very wet events over the continent (spatially averaged rainfall: $12 \mathrm{~mm} /$ day). Light rainfall starts near the coast at 1200, and strengthens at 1500, over an elongated belt paralleling the coast over both Somalia and Kenya. Lighter rainfall also develops further inland, especially near the Kenya-Ethiopia border. At 1800, the rain cells have strengthened and expanded to cover a large area, whose maximum intensity ( $>2 \mathrm{~mm} / \mathrm{hr}$ ) has shifted inland. A further shift is found in the evening, and by midnight the maximum rainfall is found at about $300-350 \mathrm{~km}$ from the coast. An intensification occurs at this time in the southern part of the rain belt, that is, on the eastern slopes of Mount Kenya (near $38^{\circ} \mathrm{E}, 0.5^{\circ} \mathrm{S}$ ). At 0300 the rainfall belt is still extensive and intense ( $>5 \mathrm{~mm} / \mathrm{hr}$ near Mount Kenya), then it weakens in the early morning. These events show two strong peaks in April and November, at the height of the rainy seasons, and large interannual variations. No event occurred in SOND 1998, 2005, 2008, and 2010 (all negative DMI seasons apart from 2008), while eight events each occurred in both 2006 and 2011 (which were positive DMI seasons).

Caution should be exercised since the above clusters are broad and aggregate more complex events than portrayed in the mean patterns. Yet they suggest that the propagation of the rain cells from the coast to the interior is real and not an artifact of the averaging of the diurnal cycle on which the map of rainfall phases (Figure 1) is based. Given the timing and the direction of propagation, it is likely related to sea breeze penetration, although at night there could also be a convergence with downslope winds from highland areas (Asnani \& Kinuthia, 1979), as described in Indochina (Takahashi et al., 2010) and New Guinea (Ichikawa \& Yasunari, 2008). Interestingly, the analysis show that the days with heavy nighttime rainfall at some distance of the coast (hence resulting in a phase shift from afternoon to the night as discussed above) also display more widespread rainfall during the afternoon which is more intense near the coast (cluster 5). The inland propagation of these precipitation cells, and their possible interactions with the topography, may explain the strong nighttime maximum.

\subsection{Relationships With Intraseasonal and Interannual Climate Drivers}

The relationship between these clusters and the Madden-Julian Oscillation is examined via a contingency table in which each day is classified according to the rainfall cluster to which it belongs and the MJO phase (Table 1). Only days with MJO amplitude greater than one (61\% of the days for the RMM index) are considered, and all months are combined. The patterns obtained on a seasonal basis (MAMJ and SOND) are basically similar (see Supporting Information S2), though more noisy because of fewer days for each MJO/cluster combination. Broadly similar patterns are found for both definitions of the MJO (RMM and OMI; see S2), although the chi-square statistic is higher when using the RMM index ( $\chi^{2}=220$ as against 146.4 for OMI). Therefore, only the results for the whole year obtained using RMM are displayed in Table 1.

Cluster 1 (dry days or isolated rains) is not strongly modulated by the MJO, although this masks out slight discrepancies between seasons (see Table S2). This can be explained by the fact that dry conditions are associated with a variety of synoptic and interannual drivers in Eastern Africa. Other clusters are strongly constrained by the MJO phase. Clusters 3-5 (rain events over the continent) show quite similar patterns, with more events during phases 1-3. These are phases associated with large-scale convection over Africa and the Indian Ocean. Minimum occurrences are found during phases 6 and 7, during which large-scale convection develops over the MC and western Pacific. Cluster 5 (strong, widespread rain events) displays the tightest phase-relationship with the MJO: $51.9 \%$ of the events are concentrated in phases 2 and 3 . Intense rainfall events over the Kenya Highlands, depicted by the $5 \%$ wettest days of a regional index, were found to be strongly modulated by the MJO (Pohl \& Camberlin, 2006b). By contrast, very few of the events (3.8\%) develop during phases 6 and 7. For the southern Somalia rainfall events (cluster 3), the MJO-phase relationship is less tight and the events tend to occur slightly earlier (peak in phase 1). The concentration of the wet events between phases 1 and 3, for the three clusters, is associated with the occurrence of midtropospheric westerly anomalies and enhanced upper easterlies (Pohl \& Camberlin, 2006a). 

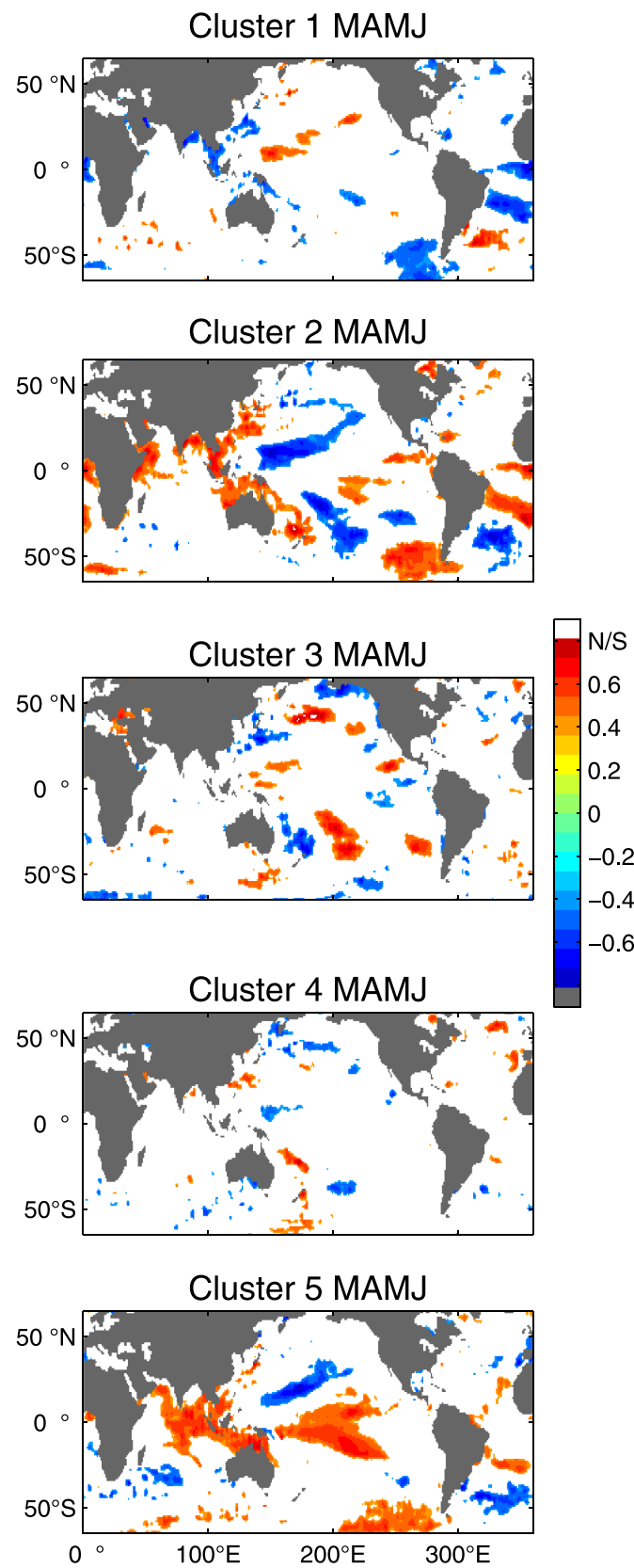

\section{Cluster 1 SOND}

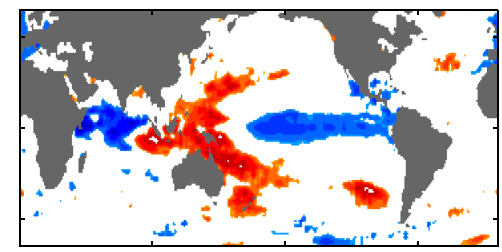

Cluster 2 SOND
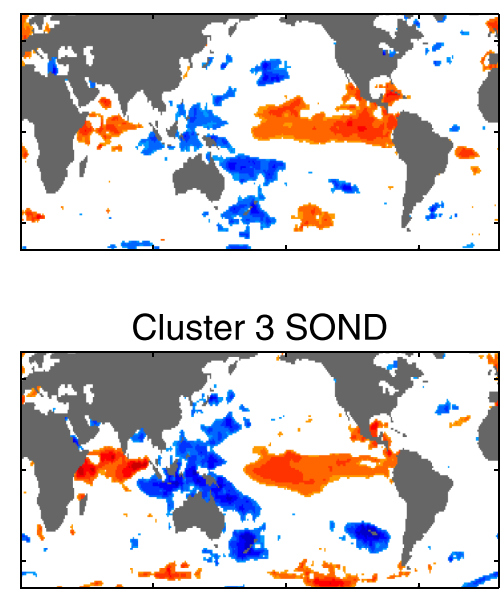

Cluster 4 SOND

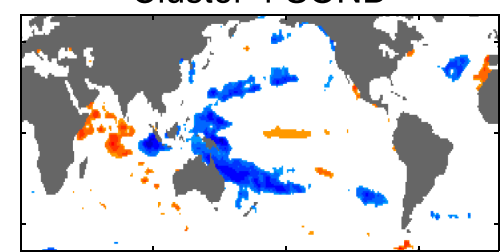

\section{Cluster 5 SOND}

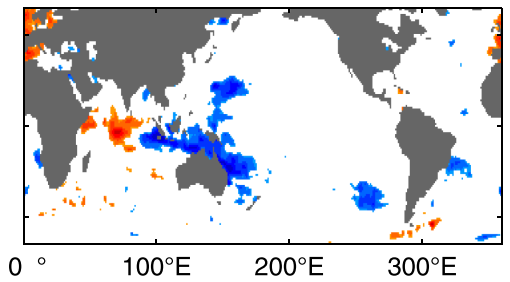

Figure 11. Correlation coefficients between seasonally averaged sea surface temperature (1998-2014) and the total number of days of each rainfall cluster during a season, for (left panels) MAMJ and (right panels) SOND. Nonsignificant correlations $(p=0.10)$ are in white.

For the Indian Ocean rainfall events (cluster 2), there is a very strong modulation by the MJO but the phase relationship differs from that of the other clusters. Maximum occurrence (26.7\%) is found during phase 1 and over 15\% during phase 2, but many events also fall during phases 7 and 8, which are drier inland. Reciprocally, MJO phases 4 and 5 rarely see the development of oceanic rainfall events (about $4 \%$ for each phase). This early activity (while large-scale convection is located along the Atlantic Ocean longitudes), which agrees with the composites presented in section 4.1, was attributed to shallow convection or stratiform rains, since positive outgoing longwave radiation (OLR) anomalies do occur during these MJO phases, suggesting an absence of deep convection (Hogan et al., 2015; Pohl \& Camberlin, 2006a).

Interannual variations in the occurrence of each cluster are next examined, separately for the MAMJ and SOND seasons. Correlation coefficients with global SST (Figure 11), the DMI, and the Niño3.4 index 
Table 2

Pearson Correlation Coefficients Between Interannual MAMJ and SOND Occurrence of Daily Rainfall Clusters 1-5 and MAMJ and SOND Sea Surface Temperature Indices (DMI and Niño3.4), 1998-2014

\begin{tabular}{|c|c|c|c|c|c|c|}
\hline & & \multicolumn{5}{|c|}{ Rainfall clusters } \\
\hline & & 1 (dry) & 2 (wet Indian Ocean) & 3 (wet, Somalia) & 4 (wet, Kenya) & 5 (very wet, Kenya and Somalia) \\
\hline \multirow[t]{2}{*}{ March-June } & DMI & 0.03 & 0.24 & 0.01 & -0.04 & $-0.52^{*}$ \\
\hline & Niño3.4 & -0.14 & 0.20 & -0.15 & -0.05 & $0.50^{*}$ \\
\hline \multirow[t]{2}{*}{ September-December } & DMI & $-0.86^{* *}$ & $0.57^{*}$ & $0.67 * *$ & $0.71^{* *}$ & $0.70^{* *}$ \\
\hline & Niño3.4 & $-0.55^{*}$ & $0.52^{*}$ & $0.53^{*}$ & 0.39 & 0.20 \\
\hline
\end{tabular}

Note. Significant values are in bold $\left({ }^{*} p=0.05,{ }^{* *} p=0.01\right)$. Correlations between DMI and Niño3.4 are -0.23 and 0.52 , for March-June and September-December, respectively.

(Table 2) are computed over the 17-year period 1998-2014. In March-June, years with many dry days (cluster 1) are weakly associated with SST anomalies, except for the South Atlantic Ocean where cold SST accompany dry years. Clusters 3 and 4 also display a weak relationship with SST. By contrast, cluster 2 (wet events over the Indian Ocean) coincides with relatively warm conditions over the western Indian Ocean, the Maritime Continent, the South Atlantic Ocean, and cold conditions over parts of the Pacific Ocean. It is speculated that the warm SST over the western Indian Ocean favor convective instability. Cluster 5 (very wet days over the continent) is clearly associated with warm waters over much of the eastern Indian Ocean and the central Pacific. It is actually the only cluster in MAMJ associated with both the IODM and ENSO (Table 2), although these modes of variability are weak or poorly defined at this time of the year.

During SOND, weak negative correlations with the Niño 3.4 index (Table 2) are found for cluster 1 (more dry days in cold years in the Pacific), and weak positive correlations for clusters 2 and 3 (more wet days on the coast and in southern Somalia in warm years in the Pacific). These correlations are well portrayed on the maps as well (Figure 11). The correlations are much higher with the DMI, and highly significant ( $p=0.01)$ for all clusters except cluster 2 , where the correlation is weaker $(0.57)$ but still significant $(p=0.05)$. This confirms the well-known effect of variations in the east-west SST gradient across the Indian Ocean on Eastern Africa SOND rainfall, which is strongly enhanced in positive DMI years. A distinct feature of cluster 5 (very wet events) is that the two years having by far the greatest number of days in this cluster, 2006 and 2011 (Figure 10), are those for which the September-November DMI is highest. Correlations with SST fields (Figure 11) actually show that while wet clusters 2-4 all display significant values in both the Indian Ocean and eastern Pacific (albeit weaker), cluster 5 is the only one which displays significant values across the Indian Ocean and MC only. This suggests that Indian Ocean SSTs are key in the occurrence of heavy, large-scale rainfall events over Eastern Africa.

The small sample of years available makes the search for the combined effects of the MJO and IODM uneasy to address, but from the above findings some interesting features emerge. While wet events show a phase-locking on both the MJO and interannual SST forcing, the occurrence of dry days over the whole region, while being strongly associated with SST, has a less tight phase-locking with the MJO. This suggests that a number of such days may still occur in otherwise active phases of the oscillation. Why such dry days occur while the intraseasonal context is favorable to rainfall is an open question, which would need to consider the role of other equatorial waves and their interaction with the diurnal cycle.

At the interannual time scale, while in SOND the SST forcing affects all categories of rainfall events, in MAMJ only the Indian Ocean rainfall events and, over the continent, the stronger events (in terms of intensity, size, and duration across the diurnal cycle) seem to be affected by SST variations. The frequency of the MAMJ weaker events (afternoon convection, with a westward shift and general decline toward the middle of the night) is not controlled by SSTs. This helps understand the overall weak SST control on Eastern Africa boreal spring rainfall (Camberlin \& Philippon, 2002; Nicholson, 2015; Ogallo et al., 1988), and suggests the utility of taking into account the diurnal cycle in order to better comprehend the effects of large-scale forcings on precipitation. 


\section{Discussion and Conclusion}

Eastern Africa is an ideal area to study the interactions between large-scale modes of variability and the diurnal cycle, given the strong diurnal modulation of rainfall and the incidence of both intraseasonal (MJO) and interannual variability (ENSO and Indian Ocean Dipole Mode) on rainfall. Composite analyses based on the different phases of the MJO and the IODM, during the October-December season, reveal that while the general features of diurnal precipitation distribution remain quite robust over time, there exist several regional deviations which illuminate valuable mechanistic arguments concerning rainfall generation.

The analysis of daily TMPA precipitation over the period 1998-2014 confirmed that the MJO strongly modulates the precipitation field over the region, with a lag in the MJO phase during which peak rainfall occurs (MJO phase 8 near the Indian Ocean coast, phase 1 in southern Somalia, and phase 3 in Tanzania). An analysis of variance indicated that over much of Kenya, eastern Uganda, central Tanzania, southern Somalia, and parts of the Indian Ocean, at least half of the diurnal precipitation cycle is significantly modulated by the MJO. The MJO mainly affects the amplitude of the diurnal cycle, by enhancing rainfall during the wettest part of the day (generally 1500 or 1800 EAT over land) when the MJO is in its active phase. However, evidence is also found of enhanced rainfall at nighttime in several land areas, suggesting variations in the duration of the rains. The timing of the peak period shows little variation, with a few exceptions (e.g., southern Somalia where during phase 1 of the oscillation the main peak shifts from 1800 to 2400, a likely consequence of more robust rain cells). This apparent weak impact of the MJO on diurnal rainfall phases contrasts with Sakaeda et al. (2017) who found that over the MC islands, the phase of the diurnal cycle is often delayed during the enhanced convective envelope of the MJO. This discrepancy partly arises from the fact that the present study analyses the timing of the actual rainfall peak, while anomalies of the probability distribution functions (PDF) are considered in Sakaeda et al. (2017). Over the western Indian Ocean, MJO variations in the timing of the peak are more complex but not very meaningful because of the relatively noisy diurnal phase patterns. Although not addressed in the present study, equatorial waves other than the MJO may also modulate diurnal rainfall in Eastern Africa. Nguyen and Duvel (2008) showed that the passage of Kelvin waves over the Congo Basin enhances diurnal convective systems, although their timing is not influenced significantly.

At the interannual time scale, over most of Eastern Africa and the nearby Indian Ocean, rainfall is known to be strongly enhanced during the positive phase of the IODM. The projection of the IODM on the diurnal rainfall variations reveals that the increase during the positive phase affects almost all times of the day. However, the enhancement is more prominent during the wettest part of the day; hence, interannual changes in the diurnal cycle primarily affect the amplitude of the cycle. As for the MJO, evidence is also found of an increased rainfall during the night. This can mean longer-lasting rainfall systems. However, in some regions the changes associated with the IODM mainly affect the diurnal phase. Besides small shifts in the main, generally afternoon peak (earlier by one 3-hourly period in DMI+ years), there are examples of more substantial changes over land areas where a significant proportion of nighttime rainfall occurs, especially regions away from the coastlines, lakes and mountain ranges, like in eastern Kenya and central Tanzania. In such cases, DMI+ years result in the main peak being found at nighttime instead of the afternoon, resulting in a 6- to 9-hr lag in the rainfall phase. It is suggested that this pattern reflects the role of convective disturbances generated in the afternoon and being stronger and longer-lasting in DMI+ years, thus travelling over greater distances and providing substantial rainfall in the night at locations which are free from such disturbances in DMI- years.

Another deviation from the general relationship with the IODM is found in the northwestern parts of Eastern Africa (South Sudan, western Uganda, western Ethiopia) where rainfall is depressed during positive phases of the IODM. This is consistent with Indeje et al. (2000) who showed that these regions have a different rainfall response to the ENSO phenomenon. It is found that this mostly results from weaker convection during the afternoon and evening hours. Finally, over the Indian Ocean, the enhancement of the rains in positive IODM phases is shown to be uniformly distributed during the day, although this is not as true near the coast where some phase shifts do occur.

On the whole, the initial hypothesis that intraseasonal and interannual large-scale forcings mostly affect the intensity of the dominant convective peak in the afternoon is, at first approximation, verified. This is in line with findings from comparable work carried out on other tropical regions, like the Andes of Colombia 
(Poveda et al., 2005) and the Maritime Continent (Peatman et al., 2014; Rauniyar \& Walsh, 2013). Peatman et al. (2014) for instance found that $80 \%$ of the MJO precipitation signal over the MC is accounted for by changes in the amplitude of the diurnal cycle. This suggests that these forcings provide conditions for more convective instability, which best express themselves at the peak of diurnal heating.

However, in several parts of Eastern Africa the effects on the diurnal cycle, at least with regards to interannual forcings, are far more complex. Diurnal phase shifts found between positive and negative IODM events suggest that large-scale forcings also affect the lifespan and propagation of precipitation cells. In particular, the cross sections and phase mapping carried out in our study, complemented by a cluster analysis of diurnal rainfall patterns over the Kenya-southern Somalia subregion, tend to indicate that diurnal phase shifts or the appearance of a second nighttime peak besides the afternoon one may be associated with longer-lived rainfall systems. Whether this results from the buildup of more intense and larger convective systems or from changes in the atmospheric circulation (e.g., direction of the synoptic-scale winds, more or less deep inland penetration of the sea breeze as a result of changes in the land-sea temperature gradient) needs to be investigated. The part played by sea breezes in explaining local discrepancies in the relationship between the MJO or ENSO and rainfall was actually pointed out by several authors working on the MC islands or the Pacific Ocean (Birch et al., 2016; Fujita et al., 2011; Hopuare et al., 2019; Kanamori et al., 2013; Qian et al., 2013). Another scientific issue is the additive and competitive effects of the MJO and IODM, which, however, requires a bigger sample of years to be adequately addressed.

\section{Acknowledgments}

This study has been carried as part of the DIRA project (Diurnal Rainfall Monitoring for Eastern Africa), with support from Pamoja-PHC (KenyaFrance Hubert Curien Partnership), thanks to the French Ministry of Higher Education, Research and Innovation (MESRI), Ministry of Europe and Foreign Affairs (MEAE), and the Kenyan Ministry of Education through the National Research Fund (NRF). All data in this paper are publicly available. The TMPA rainfall data are available online (https://pmm.nasa.gov/dataaccess/downloads/trmm). The SST data were taken from the HadISST1 data set (https://www.metoffice.gov.uk/ hadobs/hadisst) and the NOAA OISST data set (https://www.ncdc.noaa.gov/ oisst). The MJO indices were downloaded from the Bureau of Meteorology (http://www.bom.gov.au/climate/mjo, for the RMM index) and the NOAA Earth System Research Laboratory (https://www.esrl.noaa.gov/psd/mjo/ mjoindex, for OMI).

\section{References}

Anyah, R. O., Semazzi, F. H., \& Xie, L. (2006). Simulated physical mechanisms associated with climate variability over Lake Victoria Basin in East Africa. Monthly Weather Review, 134(12), 3588-3609. https://doi.org/10.1175/mwr3266.1

Asnani, G. C., \& Kinuthia, J. H. (1979). Diurnal variation of precipitation in East Africa. Nairobi, Kenya: Kenya Meteorological Department Research Report. 8/79, 58 pp.

Behera, S. K., Luo, J.-J., Masson, S., Delecluse, P., Gualdi, S., Navarra, A., \& Yamagata, T. (2005). Paramount impact of the Indian Ocean Dipole on the East African short rains: A CGCM study. Journal of Climate, 18(21), 4514-4530. https://doi.org/10.1175/jcli3541.1

Berhane, F., \& Zaitchik, B. (2014). Modulation of Daily Precipitation over East Africa by the Madden-Julian Oscillation. Journal of Climate, 27(15), 6016-6034. https://doi.org/10.1175/JCLI-D-13-00693.1

Biasutti, M., Yuter, S. E., Burleyson, C. D., \& Sobel, A. H. (2012). Very high resolution rainfall patterns measured by TRMM precipitation radar: seasonal and diurnal cycles. Climate Dynamics, 39(1-2), 239-258. https://doi.org/10.1007/s00382-011-1146-6

Birch, C. E., Webster, S., Peatman, S. C., Parker, D. J., Matthews, A. J., Li, Y., \& Hassim, M. E. E. (2016). Scale interactions between the MJO and the western Maritime Continent. Journal of Climate, 29(7), 2471-2492. https://doi.org/10.1175/jcli-d-15-0557.1

Black, E. (2005). The relationship between Indian Ocean sea-surface temperature and East African rainfall. Philosophical Transactions of the Royal Society A, 363, 43-47. https://doi.org/10.1098/rsta.2004.1474

Black, E., Slingo, J. M., \& Sperber, K. R. (2003). An observational study of the relationship between excessively strong short rains in coastal East Africa and Indian Ocean SST. Monthly Weather Review, 103, 74-94. https://doi.org/10.1175/1520-0493(2003)131<0074:aosotr>2.0. $\mathrm{co} ; 2$

Caliński, T., \& Harabasz, J. (1974). A dendrite method for cluster analysis. Communications in Statistics - Theory and Methods, 3, 1-27. https://doi.org/10.1080/03610927408827101

Camberlin, P., Gitau, W., Planchon, O., Dubreuil, V., Funatsu, B. M., \& Philippon, N. (2017). Major role of water bodies on diurnal precipitation regimes in Eastern Africa. International Journal of Climatology, 38(2), 613-629. https://doi.org/10.1002/joc.5197

Camberlin, P., Janicot, S., \& Poccard, I. (2001). Seasonality and atmospheric dynamics of the teleconnection between African rainfall and tropical sea-surface temperature: Atlantic vs. ENSO. International Journal of Climatology, 21(8), 973-1005. https://doi.org/10.1002/ joc. 673

Camberlin, P., \& Philippon, N. (2002). The east African March-May rainy season: Associated atmospheric dynamics and predictability over the 1968-97 period. Journal of Climate, 1, 1002-1019. https://doi.org/10.1175/1520-0442(2002)015<1002:teammr>2.0.co;2

Camberlin, P., \& Planchon, O. (1997). Coastal precipitation regimes in Kenya. Geografiska Annaler. Series A, Physical Geography, 79(1-2), 109-119. https://doi.org/10.1111/j.0435-3676.1997.00010.x

Cattani, E., Merino, A., \& Levizzani, V. (2016). Evaluation of monthly satellite-derived precipitation products over East Africa. Journal of Hydrometeorology, 17(10), 2555-2573. https://doi.org/10.1175/jhm-d-15-0042.1

Crétat, J., Richard, Y., Pohl, B., Rouault, M., Reason, C., \& Fauchereau, N. (2012). Recurrent daily rainfall patterns over South Africa and associated dynamics during the core of the austral summer. International Journal of Climatology, 32(2), 261-273. https://doi.org/ $10.1002 /$ joc. 2266

Dai, A., \& Wigley, T. M. L. (2000). Global patterns of ENSO-induced precipitation. Geophysical Research Letters, 27(9), $1283-1286$. https://doi.org/10.1029/1999gl011140

Deshpande, N. R., \& Goswami, B. N. (2014). Modulation of the diurnal cycle of rainfall over India by intraseasonal variations of Indian summer monsoon. International Journal of Climatology, 34, 793-807. https://doi.org/10.1002/joc.3719

Diem, J. E., Hartter, J., Ryan, S. J., \& Palace, M. W. (2014). Validation of satellite rainfall products for western Uganda. Journal of Hydrometeorology, 15(5), 2030-2038. https://doi.org/10.1175/jhm-d-13-0193.1

Dinku, T., Ceccato, P., Grover-Kopec, E., Lemma, M., Connor, S. J., \& Ropelewski, C. F. (2007). Validation of satellite rainfall products over East Africa's complex topography. International Journal of Remote Sensing, 28(7), 1503-1526. https://doi.org/10.1080/ 01431160600954688

Donald, A., Meinke, H., Power, B., de H N Maia, A., Wheeler, M. C., White, N., et al. (2006). Near-global impact of the Madden-Julian Oscillation on rainfall. Geophysical Research Letters, 33, L09704. https://doi.org/10.1029/2005gl025155 
Downing, C., Preston, F., Parusheva, D., Horrocks, L., Edberg, O., Semazzi, F., ... \& Nyangena, W. (2008). Kenya: climate screening and information exchange. Report no. AEA/ED05603, 2.

Flohn, H., \& Fraedrich, K. (1966). Tagesperiodische zirkulation und niederschlagsverteilung am Victoria-See (Ostafrika). Meteorologische Rundschau, 19(6), 157-165.

Fujita, M., Yoneyama, K., Mori, S., Nasuno, T., \& Satoh, M. (2011). Diurnal convection peaks over the eastern Indian Ocean off Sumatra during different MJO phases. Journal of the Meteorological Society of Japan, 89, 317-330. https://doi.org/10.2151/ jmsj.2011-a22

Gitau, W., Camberlin, P., Ogallo, L., \& Okoola, R. (2015). Oceanic and atmospheric linkages with short rainfall season intraseasonal statistics over Equatorial Eastern Africa and their predictive potential. International Journal of Climatology, 35(9), 2382-2399. https://doi. org/10.1002/joc.4131

Gitau, W., Ogallo, L. J., Camberlin, P., \& Okoola, R. (2013). Spatial coherence and potential predictability assessment of intraseasonal statistics of wet and dry spells over Equatorial Eastern Africa. International Journal of Climatology, 33(12), 2690-2705. https://doi.org/ $10.1002 /$ joc. 3620

Haile, A. T., Habib, E., Elsaadani, M., \& Rientjes, T. (2013). Inter-comparison of satellite rainfall products for representing rainfall diurnal cycle over the Nile basin. International Journal of Applied Earth Observation and Geoinformation, 21, 230-240. https://doi.org/10.1016/j. jag.2012.08.012

Hastenrath, S., Nicklis, A., \& Greischar, L. (1993). Atmospheric-hydrospheric mechanisms of climate anomalies in the western equatorial Indian Ocean. Journal of Geophysical Research, 98, 20,219-20,235. https://doi.org/10.1029/93jc02330

Hogan, E., Shelly, A., \& Xavier, P. (2015). The observed and modelled influence of the Madden-Julian Oscillation on East African rainfall. Meteorological Applications, 22, 459-469. https://doi.org/10.1002/met.1475

Hopuare, M., Guglielmino, M., \& Ortega, P. (2019). Interactions between intraseasonal and diurnal variability of precipitation in the South Central Pacific: The case of a small high island, Tahiti, French Polynesia. International Journal of Climatology, 39, 670-686. https://doi. org/10.1002/joc.5834

Huffman, G. J., Bolvin, D. T., Nelkin, E. J., Wolff, D. B., Adler, R. F., Gu, G., et al. (2007). The TRMM multisatellite precipitation analysis (TMPA): Quasi-global, multiyear, combined-sensor precipitation estimates at fine scales. Journal of Hydrometeorology, 8(1), 38-55. https://doi.org/10.1175/jhm560.1

Ichikawa, H., \& Yasunari, T. (2008). Intraseasonal variability in diurnal rainfall over New Guinea and the surrounding oceans during austral summer. Journal of Climate, 21(12), 2852-2868. https://doi.org/10.1175/2007jcli1784.1

Indeje, M., Semazzi, F. H. M., \& Ogallo, L. J. (2000). ENSO signals in East African rainfall and their prediction potentials. International Journal of Climatology, 20, 19-46. https://doi.org/10.1002/(sici)1097-0088(200001)20:1<19::aid-joc449>3.0.co;2-0

Kanamori, H., Yasunari, T., \& Kuraji, K. (2013). Modulation of the diurnal cycle of rainfall associated with the MJO observed by a dense hourly rain gauge network at Sarawak, Borneo. Journal of Climate, 26(13), 4858-4875. https://doi.org/10.1175/jcli-d-12-00158.1

Kiladis, G. N., Dias, J., Straub, K. H., Wheeler, M. C., Tulich, S. N., Kikuchi, K., et al. (2014). A comparison of OLR and circulation-based indices for tracking the MJO. Monthly Weather Review, 142(5), 1697-1715. https://doi.org/10.1175/mwr-d-13-00301.1

Kiladis, G. N., \& Diaz, H. F. (1989). Global climatic anomalies associated with extremes in the Southern Oscillation. Journal of Climate, 2 1069-1090. https://doi.org/10.1175/1520-0442(1989)002<1069:gcaawe>2.0.co;2

Liu, P., Zhang, Q., Zhang, C., Zhu, Y., Khairoutdinov, M., Kim, H.-M., et al. (2016). A revised real-time multivariate MJO index. Monthly Weather Review, 144(2), 627-642. https://doi.org/10.1175/mwr-d-15-0237.1

Lu, J., Li, T., \& Wang, L. (2019). Precipitation diurnal cycle over the Maritime Continent modulated by the MJO. Climate Dynamics, 53(9-10), 6489-6501. https://doi.org/10.1007/s00382-019-04941-8

Matthews, A. J., Hoskins, B. J., \& Masutani, M. (2004). The global response to tropical heating in the Madden-Julian oscillation during the northern winter. Quarterly Journal of the Royal Meteorological Society, 130(601), 1991-2011. https://doi.org/10.1256/qj.02.123

Meehl, G. A., Lukas, R., Kiladis, G. N., Weickmann, K. M., Matthews, A. J., \& Wheeler, M. (2001). A conceptual framework for time and space scale interactions in the climate system. Climate Dynamics, 17(10), 753-775. https://doi.org/10.1007/s003820000143

Meisner, B. N., \& Arkin, P. A. (1987). Spatial and annual variations in the diurnal cycle of large-scale tropical convective cloudiness and precipitation. Monthly Weather Review, 115(9), 2009-2032. https://doi.org/10.1175/1520-0493(1987)115<2009:saavit>2.0.co;2

Michelangeli, P. A., Vautard, R., \& Legras, B. (1995). Weather regimes: Recurrence and quasi stationarity. Journal of the Atmospheric Sciences, 52(8), 1237-1256. https://doi.org/10.1175/1520-0469(1995)052<1237:wrraqs >2.0.co;2

Monsieurs, E., Kirschbaum, D. B., Tan, J., Mateso, J.-C. M., Jacobs, L., Plisnier, P.-D., et al. (2018). Evaluating TMPA rainfall over the sparsely gauged East African Rift. Journal of Hydrometeorology, 19(9), 1507-1528. https://doi.org/10.1175/jhm-d-18-0103.1

Moron, V., Barbero, R., Evans, J. P., Westra, S., \& Fowler, H. J. (2019). Weather Types and Hourly to Multiday Rainfall Characteristics in Tropical Australia. Journal of Climate, 32, 3983-4011. https://doi.org/10.1175/jcli-d-18-0384.1

Moron, V., Robertson, A. W., Qian, J. H., \& Ghil, M. (2015). Weather types across the Maritime Continent: from the diurnal cycle to interannual variations. Frontiers in Environmental Science, 2, 65. https://doi.org/10.3389/fenvs.2014.00065

Nguyen, H., \& Duvel, J.-P. (2008). Synoptic Wave Perturbations and Convective Systems over Equatorial Africa. Journal of Climate, 21, 6372-6388. https://doi.org/10.1175/2008jcli2409.1

Nicholson, S. E. (1996). A review of climate dynamics and climate variability in Eastern Africa. In T. C. Johnson \& E. O. Odada (Eds.), The limnology, climatology and paleoclimatology of the east african lakes (pp. 25-56). Gordon and Breach. https://doi.org/10.1201/ 9780203748978-2

Nicholson, S. E. (2015). The predictability of rainfall over the Greater Horn of Africa. Part II: Prediction of monthly rainfall during the long rains. Journal of Hydrometeorology, 16(5), 2001-2012. https://doi.org/10.1175/jhm-d-14-0138.1

Nicholson, S. E., \& Kim, J. (1997). The relationship of the El Niño-Southern oscillation to African rainfall. International Journal of Climatology, 17(2), 117-135. https://doi.org/10.1002/(sici)1097-0088(199702)17:2<117::aid-joc84>3.0.co;2-o

Ogallo, L. J. (1988). Relationship between seasonal rainfall in East Africa and Southern Oscillation. International Journal of Climatology, 8 , 31-43. https://doi.org/10.1002/joc.3370080104

Ogallo, L. J., Janowiak, J. E., \& Halpert, M. S. (1988). Teleconnection between seasonal rainfall over East Africa and global sea-surface temperature anomalies. Journal of the Meteorological Society of Japan, 66-6(Ser. II), 807-822. https://doi.org/10.2151/ jmsj1965.66.6_807

Oh, J. H., Kim, K. Y., \& Lim, G. H. (2012). Impact of MJO on the diurnal cycle of rainfall over the western Maritime Continent in the austral summer. Climate Dynamics, 38(5-6), 1167-1180. https://doi.org/10.1007/s00382-011-1237-4

Omeny, P. A., Ogallo, L., Okoola, R., Hendon, H., \& Wheeler, M. (2008). East African rainfall variability associated with the Madden-Julian Oscillation. Journal of Kenya Meteorological Society, 2(2), 109-118. 
Peatman, S. C., Matthews, A. J., \& Stevens, D. P. (2014). Propagation of the Madden-Julian Oscillation through the Maritime Continent and scale interaction with the diurnal cycle of precipitation. Quarterly Journal of the Royal Meteorological Society, 140(680), 814-825. https://doi.org/10.1002/qj.2161

Philippon, N., Camberlin, P., \& Fauchereau, N. (2002). Empirical predictability study of October-December East African rainfall. Quarterly Journal of the Royal Meteorological Society, 128, 2239-2256. https://doi.org/10.1256/qj.01.190

Pohl, B., \& Camberlin, P. (2006a). Influence of the Madden-Julian Oscillation on East African rainfall. I: Intraseasonal variability and regional dependency. Quarterly Journal of the Royal Meteorological Society, 132(621), 2521-2539. https://doi.org/10.1256/qj.05.104

Pohl, B., \& Camberlin, P. (2006b). Influence of the Madden-Julian Oscillation on East African rainfall: II. March-May season extremes and interannual variability. Quarterly Journal of the Royal Meteorological Society, 132(621), 2541-2558. https://doi.org/10.1256/qj.05.223

Poveda, G., Mesa, O. J., Salazar, L. F., Arias, P. A., Moreno, H. A., Vieira, S. C., et al. (2005). The diurnal cycle of precipitation in the tropical Andes of Colombia. Monthly Weather Review, 133(1), 228-240. https://doi.org/10.1175/mwr-2853.1

Qian, J. H., Robertson, A. W., \& Moron, V. (2010). Interactions among ENSO, the monsoon, and diurnal cycle in rainfall variability over Java, Indonesia. Journal of the Atmospheric Sciences, 67, 3509-3524. https://doi.org/10.1175/2010jas3348.1

Qian, J. H., Robertson, A. W., \& Moron, V. (2013). Diurnal cycle in different weather regimes and rainfall variability over Borneo associated with ENSO. Journal of Climate, 26(5), 1772-1790.

Rauniyar, S. P., \& Walsh, K. J. (2011). Scale interaction of the diurnal cycle of rainfall over the Maritime Continent and Australia: Influence of the MJO. Journal of Climate, 24(2), 325-348. https://doi.org/10.1175/2010jcli3673.1

Rauniyar, S. P., \& Walsh, K. J. (2013). Influence of ENSO on the diurnal cycle of rainfall over the Maritime Continent and Australia. Journal of Climate, 26(4), 1304-1321. https://doi.org/10.1175/jcli-d-12-00124.1

Rayner, N. A., Parker, D. E., Horton, E. B., Folland, C. K., Alexander, L. V., Rowell, D. P., et al. (2003). Global analyses of sea surface temperature, sea ice, and night marine air temperature since the late nineteenth century. Journal of Geophysical Research, 108(D14), 4407. https://doi.org/10.1029/2002jd002670

Reynolds, R. W., Rayner, N. A., Smith, T. M., Stokes, D. C., \& Wang, W. (2002). An improved in situ and satellite SST analysis for climate. Journal of Climate, 15, 1609-1625. https://doi.org/10.1175/1520-0442(2002)015<1609:aiisas >2.0.co;2

Ropelewski, C. F., \& Halpert, M. S. (1987). Global and regional scale precipitation patterns associated with the El Niño/Southern Oscillation. Monthly Weather Review, 115(8), 1606-1626. https://doi.org/10.1175/1520-0493(1987)115<1606:garspp>2.0.co;2

Ruane, A. C., \& Roads, J. O. (2007). 6-Hour to 1-Year Variance of Five Global Precipitation Sets. Earth Interactions, 11, 1-29. https://doi. org/10.1175/ei225.1

Saji, N. H., Goswami, B. N., Vinayachandran, P. N., \& Yamagata, T. (1999). A dipole mode in the tropical Indian Ocean. Nature, 401(6751), 360-363. https://doi.org/10.1038/43854

Sakaeda, N., Kiladis, G. N., \& Dias, J. (2017). The Diurnal Cycle of Tropical Cloudiness and Rainfall Associated with the Madden-Julian Oscillation. Journal of Climate, 30, 3999-4020. https://doi.org/10.1175/JCLI-D-16-0788.1

Sen Roy, S., \& Balling, R. C. Jr. (2007). Diurnal variations in summer season precipitation in India. International Journal of Climatology, 27(7), 969-976. https://doi.org/10.1002/joc.1458

Seo, K. H., \& Son, S. W. (2012). The global atmospheric circulation response to tropical diabatic heating associated with the Madden-Julian oscillation during northern winter. Journal of the Atmospheric Sciences, 69(1), 79-96. https://doi.org/10.1175/2011jas3686.1

Suzuki, T. (2009). Diurnal cycle of deep convection in super clusters embedded in the Madden-Julian Oscillation. Journal of Geophysical Research, 114(D22), D22102. https://doi.org/10.1029/2008JD011303

Takahashi, H. G., Fujinami, H., Yasunari, T., \& Matsumoto, J. (2010). Diurnal rainfall pattern observed by Tropical Rainfall Measuring Mission Precipitation Radar (TRMM-PR) around the Indochina peninsula. Journal of Geophysical Research, 115(D7), D07109. https:// doi.org/10.1029/2009jd012155

Tian, B., Waliser, D. E., \& Fetzer, E. J. (2006). Modulation of the diurnal cycle of tropical deep convective clouds by the MJO. Geophysical Research Letters, 33, L20704. https://doi.org/10.1029/2006gl027752

Tomsett, J. E. (1975). The diurnal variation of precipitation in East Africa (Vol. 25, 66 p.). EAMD Technical Memorandum.

Tramblay, Y., \& Hertig, E. (2018). Modelling extreme dry spells in the Mediterranean region in connection with atmospheric circulation. Atmospheric Research, 202, 40-48. https://doi.org/10.1016/j.atmosres.2017.11.015

Ummenhofer, C. C., Sen Gupta, A., England, M. H., \& Reason, C. J. C. (2009). Contributions of Indian Ocean sea surface temperatures to enhanced East African rainfall. Journal of Climate, 22, 993-1013. https://doi.org/10.1175/2008jcli2493.1

Ventrice, M. J., Wheeler, M. C., Hendon, H. H., Schreck, C. J. III, Thorncroft, C. D., \& Kiladis, G. N. (2013). A modified multivariate Madden-Julian oscillation index using velocity potential. Monthly Weather Review, 141(12), 4197-4210. https://doi.org/10.1175/mwr-d$12-00327.1$

Wang, S., Ma, D., Sobel, A. H., \& Tippett, M. K. (2018). Propagation characteristics of BSISO indices. Geophysical Research Letters, 45(18), 9934-9943. https://doi.org/10.1029/2018gl078321

Wheeler, M. C., \& Hendon, H. (2004). An all-season real-time multivariate MJO index: Development of an index for monitoring and prediction. Monthly Weather Review, 132, 1917-1932. https://doi.org/10.1175/1520-0493(2004)132<1917:aarmmi >2.0.co;2

Yang, G. Y., \& Slingo, J. (2001). The diurnal cycle in the tropics. Monthly Weather Review, 129(4), 784-801. https://doi.org/10.1175/15200493(2001)129<0784:TDCITT>2.0.CO;2

Zaitchik, B. F. (2017). Madden-Julian Oscillation impacts on tropical African precipitation. Atmospheric Research, 184, 88-102. https://doi. org/10.1016/j.atmosres.2016.10.002

Zhang, C. (2005). Madden-Julian Oscillation. Reviews of Geophysics, 43, RG2003. https://doi.org/10.1029/2004RG000158 